\title{
Molecular and clinical profiles of syndecan-1 in solid and hematological cancer for prognosis and precision medicine
}

\author{
Mohamed R. AkI ${ }^{1}$, Poonam Nagpal' ${ }^{1}$, Nehad M. Ayoub ${ }^{2}$, Sathyen A. Prabhu ${ }^{1}$, Matthew \\ Gliksman $^{1}$, Betty Tai ${ }^{1}$, Ahmet Hatipoglu ${ }^{1}$, Andre Goy ${ }^{3}$ and K. Stephen Suh ${ }^{1}$ \\ ${ }^{1}$ Genomics and Biomarkers Program, The John Theurer Cancer Center, Hackensack University Medical Center, Hackensack, \\ NJ, USA \\ 2 Department of Clinical Pharmacy, Faculty of Pharmacy, Jordan University of Science and Technology, Irbid, Jordan \\ ${ }^{3}$ Lymphoma Division, The John Theurer Cancer Center, Hackensack University Medical Center, Hackensack, NJ, USA \\ Correspondence to: K. Stephen Suh, email: ksuh@HackensackUMC.org \\ Keywords: syndecan, biomarker, cancer, personalized medicine, CD138 \\ Received: May 27, $2015 \quad$ Accepted: July 11, $2015 \quad$ Published: July 22, 2015
}

This is an open-access article distributed under the terms of the Creative Commons Attribution License, which permits unrestricted use, distribution, and reproduction in any medium, provided the original author and source are credited.

\section{ABSTRACT}

Syndecan-1 (SDC1, CD138) is a key cell surface adhesion molecule essential for maintaining cell morphology and interaction with the surrounding microenvironment. Deregulation of SDC1 contributes to cancer progression by promoting cell proliferation, metastasis, invasion and angiogenesis, and is associated with relapse through chemoresistance. SDC1 expression level is also associated with responses to chemotherapy and with prognosis in multiple solid and hematological cancers, including multiple myeloma and Hodgkin lymphoma. At the tissue level, the expression levels of SDC1 and the released extracellular domain of SDC1 correlate with tumor malignancy, phenotype, and metastatic potential for both solid and hematological tumors in a tissue-specific manner. The SDC1 expression profile varies among cancer types, but the differential expression signatures between normal and cancer cells in epithelial and stromal compartments are directly associated with aggressiveness of tumors and patient's clinical outcome and survival. Therefore, relevant biomarkers of SDC signaling may be useful for selecting patients that would most likely respond to a particular therapy at the time of diagnosis or perhaps for predicting relapse. In addition, the reciprocal expression signature of SDC between tumor epithelial and stromal compartments may have synergistic value for patient selection and the prediction of clinical outcome.

\section{INTRODUCTION}

Syndecan structure and expression

Syndecans are members of the transmembrane heparan sulfate proteoglycan (HSPG) family [1]. Mammals have four syndecan family members, designated as syndecan-1 (syndecan, SDC1, CD138) [2], syndecan-2 (fibroglycan, SDC2) [3], syndecan-3 (N-syndecan, SDC3) [4], and syndecan-4 (amphiglycan or ryudocan, SDC4) [5]. SDC1 is the most studied and best characterized member of the syndecan family. The protein structure of syndecan consists of extracellular, transmembrane, and cytoplasmic domains (Figure 1A). The large extracellular domain of syndecan is located on the $\mathrm{N}$-terminus (ectodomain) and is comprised of glycosaminoglycan (GAG) chains (heparan sulfate and chondroitin sulfate) [6]. All syndecans are anchored to the plasma membrane via a 24-25 amino acid hydrophobic transmembrane domain, which is highly conserved among the four syndecans. The cytoplasmic domain of syndecan contains the C-terminus, which is relatively short and comprised of 28-34 amino acids (Figure 1A). Importantly, the cytoplasmic domain of syndecan can be linked to intracellular cytoskeletal elements that maintain cell shape and provide support to the cytoskeleton (Figure 1A) [6-8]. In mammalian cells, 
the expression of syndecans is tightly regulated and, in turn, may control many downstream signaling events. Syndecans show different patterns of expression in various tissues. While SDC1 is predominantly expressed in epithelial and mesenchymal cells, SDC2 is the most abundantly expressed in cells of mesenchymal origin than in neuronal and epithelial cells. In hematopoietic tissues, SDC1 is predominantly expressed on the cell surface of immature B cells and mature plasma cells [9]. SDC3 is mainly expressed in neuronal and musculoskeletal tissue, whereas SDC4 is ubiquitously expressed [10]. Evidence indicates that the expression of SDC1 can be regulated by multiple growth factors, such as tumor growth factor- $\beta$ (TGF- $\beta$ ) and basic fibroblast growth factor (bFGF or FGF2), in different mammalian cell types [11]. Tumor necrosis factor- $\alpha$ (TNF- $\alpha$ ) downregulates SDC1 expression in endothelial cells [12], whereas TGF- $\beta 2$ downregulates SDC1 expression in epithelial cells [13]. In addition, SDC1 expression is highly increased during the wound repair process [14].

\section{Syndecan localization and function}

\section{Cell surface syndecan}

Syndecan (originating from the Greek word syndein, meaning "to bind together") acts as an anchor to stabilize the morphology of epithelial sheets by connecting the extracellular matrix to the intracellular cytoskeleton [15]. Syndecan is expressed on the surface of all adherent cells and on many non-adherent cells [15]. It is well-established that syndecan serves as coreceptor for various heparinbinding growth factors, such as bFGF/FGF2, vascular endothelial growth factor (VEGF), TGF- $\beta$, and plateletderived growth factor (PDGF) (Figure 1A, 1B) [16-18]. The interaction between syndecan and growth factors is facilitated through heparan sulfate (HS) chains (Figure 1A). In this regard, HS chains serve as templates that bridge growth factors and their receptors. In the case of FGF, syndecan acts as coreceptor to enhance the binding between FGF and the FGF receptor. Such binding lowers the concentration of FGF required to initiate downstream signaling through its receptor and extends the duration of receptor signaling (Figure 1B) [19]. In addition to its role as a coreceptor, syndecan itself acts as receptor via its HS chains (Figure 1A). Syndecan binds to different matrix elements through interactions with heparan-binding molecules on adjacent cells to potentiate cell-matrix adhesion (Figure 1A) [20-22]. Examples of extracellular molecules that commonly bind to syndecan in order to mediate cell adhesion to the extracellular matrix include collagens, fibronectin, thrombospondin, and tenascin [2022].

Unlike HS chains, the biological function of

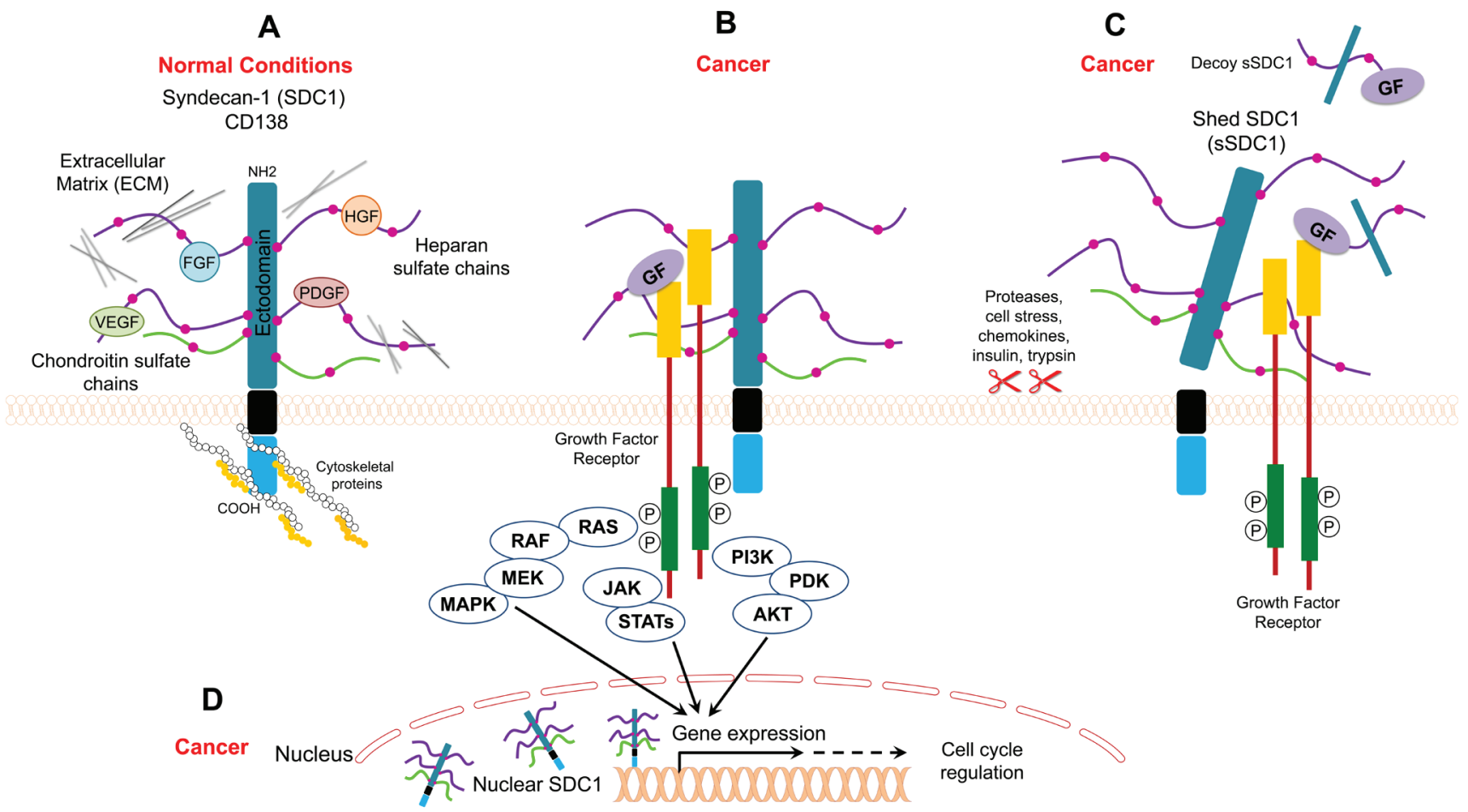

Figure 1: Model for SDC1 function under normal and cancer conditions. A. SDC1 binds to ECM proteins and/or growth factors through its heparan sulfate chains, and it binds to cytoskeletal proteins for cell anchorage $\mathbf{B}$. SDC1 acts as a coreceptor that facilitates interaction between growth factors and their receptors and enhances cancer mitogenic signaling C. Shed SDC1 (sSDC1) enhances the interaction between growth factors and their receptors in cancer or acts as a decoy receptor $\mathbf{D}$. Nuclear SDC1 controls gene expression in cancer. 
Table 1: Studies evaluating SDC1 as a prognostic biomarker in cancer patients with solid tumors.

\begin{tabular}{|c|c|c|c|c|c|c|c|c|}
\hline Cancer Type & $\begin{array}{l}\text { Patient } \\
\text { Number }\end{array}$ & $\begin{array}{l}\text { Specimen } \\
\text { Type }\end{array}$ & Cancer Subtype & $\begin{array}{l}\text { Location } \\
\text { (Method) }\end{array}$ & SDC1 Expression Pattern & Prognosis & Associated with & Ref \\
\hline \multirow[t]{6}{*}{ Bladder } & 109 & $\begin{array}{l}\text { Surgical } \\
\text { resection }\end{array}$ & NMIBC & $\begin{array}{l}\text { Epithelial } \\
\text { (IHC) }\end{array}$ & $(\downarrow)$ in tumor vs. normal urothelium & $\begin{array}{l}(\downarrow) \text { RFS in low vs. high expression } \\
(p<.001)\end{array}$ & High-stage disease & [64] \\
\hline & \multirow[t]{3}{*}{$\begin{array}{l}198 \text { vs. } 15 \\
\text { controls }\end{array}$} & \multirow[t]{3}{*}{$\begin{array}{l}\text { Untreated } \\
\text { surgical }\end{array}$} & \multirow[t]{3}{*}{ Urothelial } & $\begin{array}{l}\text { Epithelial } \\
\text { (IHC) }\end{array}$ & 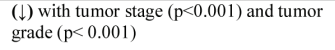 & $\begin{array}{l}\text { ( } \downarrow \text { ) DSS in negative vs. positive } \\
\text { expression }(\mathrm{p}=.021)\end{array}$ & \multirow{3}{*}{$\begin{array}{l}\text { Epithelial with low stage, } \\
\text { low-grade; stromal } \\
\text { reciprocally associated; } \\
\text { serum with high-stage, high- } \\
\text { grade, metastases }\end{array}$} & \multirow[t]{3}{*}{ [65] } \\
\hline & & & & $\begin{array}{l}\text { Stromal } \\
(\mathrm{IHC})\end{array}$ & $\begin{array}{l}\text { ( } \uparrow \text { ) with tumor stage }(\mathrm{p}=0.001) \text { and tumor } \\
\text { grade }(\mathrm{p}=0.004)\end{array}$ & 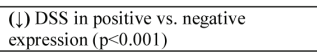 & & \\
\hline & & & & $\begin{array}{l}\text { Serum } \\
\text { (ELISA) }\end{array}$ & $(\uparrow)$ in metastatic stage $(\mathrm{p}<0.001)$ & $\begin{array}{l}(\downarrow)) \text { DSS in high }(\geq 91 \mathrm{ng} / \mathrm{mL}) \text { vs. low } \\
(<91 \mathrm{ng} / \mathrm{m}) \text { levels }(\mathrm{p}=0.075)\end{array}$ & & \\
\hline & \multirow{2}{*}{$\begin{array}{l}\text { Urine: } 102 \text { vs. } \\
206 \text { controls; } \\
\text { tissue: } 185 \text { vs. } \\
8 \text { controls }\end{array}$} & \multirow[t]{2}{*}{$\begin{array}{l}\text { Voided urine } \\
\text { and archived } \\
\text { tumor blocks }\end{array}$} & \multirow[t]{2}{*}{$\begin{array}{l}\text { NMIBC and } \\
\text { MIBC }\end{array}$} & $\begin{array}{l}\text { Epithelial } \\
\text { (IHC) }\end{array}$ & $\begin{array}{l}(\downarrow) \text { in membranous and }(\uparrow) \text { in } \\
\text { cytoplasmic SDCl in high grade tumors } \\
\text { vs. low-grade tumors }(p<0.0001)\end{array}$ & \multirow[t]{2}{*}{$\begin{array}{l}(\downarrow) \text { DSS in cytoplasmic vs. } \\
\text { membranous expression }(\mathrm{p}=0.0001)\end{array}$} & \multirow{2}{*}{$\begin{array}{l}\text { Epithelial with high-grade, } \\
\text { high stage tumors, poorly } \\
\text { differentiated, urine with } \\
\text { tumor grade, invasive-type }\end{array}$} & \multirow[t]{2}{*}[66]{} \\
\hline & & & & $\begin{array}{l}\text { Urine } \\
\text { (ELISA) }\end{array}$ & $\begin{array}{l}\text { No significant difference tumor vs. } \\
\text { control }\end{array}$ & & & \\
\hline \multirow[t]{10}{*}{ Breast } & \multirow[t]{2}{*}{80} & \multirow{2}{*}{$\begin{array}{l}\text { Irradiated } \\
\text { and hormone } \\
\text { treated } \\
\text { surgical }\end{array}$} & \multirow[t]{2}{*}{ Invasive ductal } & $\begin{array}{l}\text { Epithelial } \\
\text { (IHC) }\end{array}$ & $\begin{array}{l}61.25 \% \text { tumors positive (cutoff: }>10 \% \\
\text { positive cells) }\end{array}$ & \multirow{2}{*}{$\begin{array}{l}(\downarrow) \sim 0.6 \text { fold } 7 \text {-yr RFS in epithelial- } \\
\text { stromal+ vs. epithelial+ and/or stromal } \\
\text { expression }(p<0.0001)\end{array}$} & \multirow{2}{*}{$\begin{array}{l}\text { High epithelial expression is } \\
\text { associated with low- } \\
\text { histological grade, well- } \\
\text { differentiated tumors }\end{array}$} & \multirow[t]{2}{*}[70]{} \\
\hline & & & & $\begin{array}{l}\text { Stromal } \\
\text { (IHC) }\end{array}$ & $\begin{array}{l}(\uparrow) \text { in cancer ( } 30 \% \text {, cutoff: }>10 \% \text { of cells } \\
\text { positive) vs. absent in control }\end{array}$ & & & \\
\hline & \multirow[t]{2}{*}{$\begin{array}{l}62 \text { vs. } 10 \\
\text { controls }\end{array}$} & \multirow[t]{2}{*}{$\begin{array}{l}\text { Excisional } \\
\text { biopsy }\end{array}$} & \multirow[t]{2}{*}{$\begin{array}{l}\text { Invasive ductal } \\
\text { and lobular }\end{array}$} & $\begin{array}{l}\text { Epithelial } \\
\text { (IHC) }\end{array}$ & $\begin{array}{l}(\uparrow) \text { in tumor vs. control (breast carcinoma } \\
\text { patients without metastasis, } \mathrm{p}<0.0001 \text { ) }\end{array}$ & $\begin{array}{l}(\downarrow) \text { OS }(\mathrm{p}=0.02) \text { and } \mathrm{DSS}(\mathrm{p}=0.01) \text { in } \\
\text { high vs. low epithelial expression }\end{array}$ & \multirow[t]{2}{*}{$\begin{array}{l}\text { Histological grade; inversely } \\
\text { with hormonal receptor status }\end{array}$} & \multirow[t]{2}{*}[72]{} \\
\hline & & & & $\begin{array}{l}\text { Stromal } \\
(\mathrm{IHC})\end{array}$ & $83 \%$ tumor positive vs. $100 \%$ control & - & & \\
\hline & \multirow[t]{2}{*}{200} & \multirow[t]{2}{*}{ Surgical } & \multirow{2}{*}{$\begin{array}{l}\text { Invasive ductal, } \\
\text { lobular, medullary, } \\
\text { papillary, } \\
\text { mucinous }\end{array}$} & $\begin{array}{l}\text { Epithelial } \\
\text { (IHC) }\end{array}$ & $\begin{array}{l}61 \% \text { tumors positive (cutoff: }>5 \% \\
\text { positive cells) }\end{array}$ & $\begin{array}{l}(\downarrow) 0.7 \text { fold } 10 \mathrm{yr} \text { - OS in } \\
\text { epithelial }+ \text { /stromal }+ \text { vs. epithelial- }\end{array}$ & $\begin{array}{l}\text { DNA ploidy, ER-positive, } \\
\text { cytoplasmic staining }\end{array}$ & {$[76]$} \\
\hline & & & & $\begin{array}{l}\text { Stromal } \\
\text { (IHC) }\end{array}$ & $\begin{array}{l}67 \% \text { tumors positive (cutoff: }>5 \% \\
\text { positive cells) }\end{array}$ & and/or stromal expression $(\mathrm{p}<0.002)$ & $\begin{array}{l}\text { associated with poorly } \\
\text { differentiated tumors }\end{array}$ & \\
\hline & 127 & Surgical & DCIS & $\begin{array}{l}\text { Epithelial } \\
\text { (IHC) }\end{array}$ & $\begin{array}{l}(\uparrow) \text { in low vs. high grade tumors } \\
(\mathrm{p}=0.043)\end{array}$ & No significant difference & ER, PR negative status & [71] \\
\hline & 207 & Surgical & - & $\begin{array}{l}\text { Epithelial } \\
\text { (IHC) }\end{array}$ & $(\uparrow)$ in high grade $(p=0.0007)$ & 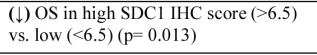 & $\begin{array}{l}\text { Tumor size, grade, } \\
\text { metastasis, ER status }\end{array}$ & {$[74]$} \\
\hline & 102 & $\begin{array}{l}\text { Surgical } \\
\text { resection }\end{array}$ & Primary invasive & $\begin{array}{l}\text { Epithelial } \\
\text { (IHC) }\end{array}$ & $\begin{array}{l}73.5 \% \text { tumors positive }(>80 \% \text { positive } \\
\text { cells) vs. absent or weak in controls }\end{array}$ & $\begin{array}{l}\text { ( } \downarrow) \text { OS in strong vs. weak SDC1 } \\
\text { staining intensity }(\mathrm{p}=0.041, \mathrm{n}=98)\end{array}$ & Inversely with PR & {$[75]$} \\
\hline & & & & $\begin{array}{l}\text { Stromal } \\
\text { (IHC) }\end{array}$ & $29.5 \%$ tumors positive & No significant difference & & \\
\hline Cervical & 121 & $\begin{array}{l}\text { Surgical } \\
\text { resection }\end{array}$ & - & $\begin{array}{l}\text { Epithelial } \\
\text { (IHC) }\end{array}$ & $83.5 \%$ tumors positive & $\begin{array}{l}(\downarrow) \text { proportion surviving in negative, } \\
\text { weak positive vs. strong staining } \\
(\mathrm{p}=0.0219)\end{array}$ & $\begin{array}{l}\text { High epithelial expression is } \\
\text { associated with low- } \\
\text { histological grade }\end{array}$ & {$[77]$} \\
\hline & 244 & $\begin{array}{l}\text { Untreated } \\
\text { surgical }\end{array}$ & $\begin{array}{l}\text { Intraepithelial, } \\
\text { microinvasive, } \\
\text { invasive }\end{array}$ & $\begin{array}{l}\text { Epithelial } \\
\text { (IHC) }\end{array}$ & $\begin{array}{l}\text { Loss of expression in tumors vs. } \\
\text { basolateral in normal cervix }\end{array}$ & No significant difference & $\begin{array}{l}\text { Squamous histology, } \\
\text { metastatic lymph nodes }\end{array}$ & {$[78]$} \\
\hline & 124 & $\begin{array}{l}\text { Untreated } \\
\text { surgical }\end{array}$ & SCC, ACA & $\begin{array}{l}\text { Epithelial } \\
\text { (IHC) }\end{array}$ & $36 \%$ tumors strong positive & No significant difference & $\begin{array}{l}\text { Differentiation grade, } \\
\text { squamous histology }\end{array}$ & [79] \\
\hline Colorectal & $\begin{array}{l}158 \text { vs. } 15 \\
\text { adenomas and }\end{array}$ & $\begin{array}{l}\text { Diagnostic } \\
\text { biopsy }\end{array}$ & $\mathrm{ACA}$ & $\begin{array}{l}\text { Epithelial } \\
\text { (IHC) }\end{array}$ & $\begin{array}{l}(\downarrow)(29 \% \text { patients negative) or loss vs. } \\
\text { normal epithelia }\end{array}$ & No significant difference & $\begin{array}{l}\text { Poor differentiation, TNM } \\
\text { staging, lymph node }\end{array}$ & {$[81]$} \\
\hline & 14 controls & & & $\begin{array}{l}\text { Stromal } \\
\text { (IHC) }\end{array}$ & $\begin{array}{l}16.6 \% \text { tumors positive vs. negative } \\
\text { normal stroma }\end{array}$ & & metastasis & \\
\hline Endometrial & 109 & Surgical & $\begin{array}{l}\text { ACA, } \\
\text { adenosquamous } \\
\text { and serous }\end{array}$ & $\begin{array}{l}\text { Epithelial } \\
\text { (IHC) }\end{array}$ & $\begin{array}{l}58 \% \text { tumors strong positive and }(\downarrow) \text { in } \\
\text { advanced stage vs. early stage }(\mathrm{p}=0.007)\end{array}$ & 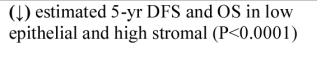 & $\begin{array}{l}\text { Advanced stage, high grade, } \\
\text { lymph node metastasis }\end{array}$ & [83] \\
\hline & & & carcinomas & $\begin{array}{l}\begin{array}{l}\text { Stromal } \\
\text { (IHC) }\end{array} \\
\end{array}$ & $\begin{array}{l}16 \% \text { tumors strong positive and }(\uparrow) \text { in } \\
\text { high grade tumors ( } \mathrm{p}=0.05 \text { ) }\end{array}$ & & & \\
\hline Gallbladder & 43 & $\begin{array}{l}\text { Untreated } \\
\text { surgical } \\
\text { resection }\end{array}$ & ACA & Epithelial & $\begin{array}{l}58.1 \% \text { tumors positive vs. absent in } \\
\text { controls }\end{array}$ & 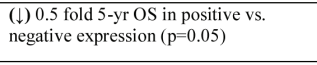 & $\begin{array}{l}\text { Lymph node metastasis, } \\
\text { lymphovascular invasion }\end{array}$ & [85] \\
\hline & & & & Stromal & No stromal expression & - & & \\
\hline Gastric & 337 & Surgical & $\mathrm{ACA}$ & $\begin{array}{l}\text { Epithelial } \\
\text { (IHC) }\end{array}$ & $31 \%$ tumors positive & $\begin{array}{l}\text { ( } \downarrow) 0.5 \text { fold cumulative } 5 \text { yr survival in } \\
\text { negative vs. positive expression } \\
(\mathrm{p}=0.002)\end{array}$ & High grade, nodal metastases & {$[86]$} \\
\hline & & & & $\begin{array}{l}\text { stromal } \\
\text { (IHC) }\end{array}$ & $9 \%$ positive & $\begin{array}{l}(\downarrow) 0.5 \text { fold cumulative } 5 \text { yr survival in } \\
\text { positive vs. negative expression } \\
(\mathrm{p}=0.038)\end{array}$ & & \\
\hline & 296 & Surgical & $\mathrm{ACA}$ & $\begin{array}{l}\text { Epithelial } \\
\text { (IHC) }\end{array}$ & $\begin{array}{l}47 \% \text { tumors positive (cutoff: }>60 \% \\
\text { cells), } 26 \% \text { negative }\end{array}$ & $\begin{array}{l}\text { ( } \downarrow) \sim 0.5 \text { fold cumulative } 5 \text {-yr survival } \\
\text { in low vs. high expression ( } \mathrm{p}=0.0012 \text { ) }\end{array}$ & $\begin{array}{l}\text { Loss of epithelial SDC1 is } \\
\text { correlated with high TNM }\end{array}$ & {$[87]$} \\
\hline & & & & $\begin{array}{l}\text { Stromal } \\
\text { (IHC) }\end{array}$ & $9 \%$ positive & $\begin{array}{l}(\downarrow) \sim 0.5 \text { fold cumulative } 5 \text {-yr survival } \\
\text { in high vs. low expression }(\mathrm{p}=0.0193)\end{array}$ & $\begin{array}{l}\text { stage, lymph node } \\
\text { metastases, large tumor size }\end{array}$ & \\
\hline Glioma & $\begin{array}{l}116 \text { vs. } 15 \\
\text { controls }\end{array}$ & $\begin{array}{l}\text { Surgical } \\
\text { resection }\end{array}$ & - & $\begin{array}{l}\text { Epithelial } \\
\text { (qRT-PCR, } \\
\text { IHC, } \\
\text { Western } \\
\text { blot) }\end{array}$ & $\begin{array}{l}(\uparrow)>2 \text { fold gene expression in tumors vs. } \\
\text { controls; }(\uparrow)>3 \text { fold protein expression in } \\
\text { tumors vs. controls }(\mathrm{p}<0.001), 82.8 \% \\
\text { positive for Immunostaining }(\mathrm{p}<0.001)\end{array}$ & 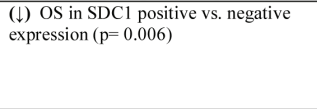 & Advanced tumor progression & {$[88]$} \\
\hline Head and Neck & 175 & $\begin{array}{l}\text { Post- } \\
\text { operative } \\
\text { irradiated } \\
\text { surgical }\end{array}$ & Primary SCC & $\begin{array}{l}\text { Epithelial } \\
\text { (IHC) }\end{array}$ & $\begin{array}{l}52.6 \% \text { tumors strong positive }(>50 \% \\
\text { cells) }\end{array}$ & $\begin{array}{l}(\downarrow) 0.7 \text { fold } 2 \text {-yr. OS in weak positive } \\
\text { (cutoff: }<50 \% \text { cells positive) vs. strong } \\
\text { positive }(>50 \% \text { cells positive), } \\
p=0.001 \text { ) }\end{array}$ & $\begin{array}{l}\text { Loss of epithelial SDC1 is } \\
\text { associated with large tumor } \\
\text { size, positive nodal status, } \\
\text { high clinical stage }\end{array}$ & [110] \\
\hline & 29 & $\begin{array}{l}\text { Untreated } \\
\text { diagnostic } \\
\text { biopsy }\end{array}$ & Primary SCC & $\begin{array}{l}\text { Epithelial } \\
\text { (IHC) }\end{array}$ & $\begin{array}{l}\text { (Џ) SDC1 expression in poor } \\
\text { differentiated tumors }(25 \% \text { patients) vs. } \\
\text { well differentiated ( } \mathrm{p}=.006) \text {, strong } \\
\text { expression in normal oral mucosa }\end{array}$ & $\begin{array}{l}(\downarrow) 0.3 \text { fold } 2 \text {-yr OS in weak or no } \\
\text { expression vs. strong positive } \\
(p=0.001) ;(\downarrow) \text {. } 0.3 \text { fold } 2 \text {-yr RFS in } \\
\text { weak expression vs. strong positive } \\
(p=.003)\end{array}$ & $\begin{array}{l}\text { Poorly differentiated tumors, } \\
\text { large tumor size }\end{array}$ & [111] \\
\hline Laryngeal & 100 & $\begin{array}{l}\text { Tissue } \\
\text { blocks }\end{array}$ & $\begin{array}{l}\text { Glottic, supra } \\
\text { glottic, and } \\
\text { transglottic }\end{array}$ & $\begin{array}{l}\text { Epithelial } \\
\text { (IHC) }\end{array}$ & $45 \%$ tumors strong positive & $\begin{array}{l}\text { ( }) 0.8 \text { fold } 5 \text {-yr OS weak or no } \\
\text { expression vs. strong expression } \\
(\mathrm{p}=.048)\end{array}$ & Poor differentiation & {$[90]$} \\
\hline Liver & 295 & Serum & $\begin{array}{l}\text { Barcelona clinic } \\
\text { liver cancer }\end{array}$ & Soluble & $\begin{array}{l}\text { ( }) \text { in patients vs. low in patients without } \\
\text { HCC or early HCC }(p<0.0001)\end{array}$ & $\begin{array}{l}\text { ( }) \text { OS in high }(>50 \mathrm{ng} / \mathrm{ml}) \text { vs. low } \\
(<50 \mathrm{ng} / \mathrm{ml}) \text { levels }(\mathrm{p}=0.006),(\downarrow) \mathrm{RFS} \\
\text { in high vs. low levels }(\mathrm{p}=0.025)\end{array}$ & $\begin{array}{l}\text { Advanced stages of primary } \\
\text { liver tumors }\end{array}$ & [91] \\
\hline & 57 & $\begin{array}{l}\text { Biopsy, } \\
\text { surgical } \\
\text { resection, } \\
\text { autopsy }\end{array}$ & $\begin{array}{l}\text { With intra or no } \\
\text { intra hepatic } \\
\text { metastatic lesion }\end{array}$ & $\begin{array}{l}\text { Epithelial } \\
\text { (IHC, } \\
\text { Northern } \\
\text { blot) }\end{array}$ & $\begin{array}{l}31.6 \% \text { tumors positive, }(\downarrow) \text { gene } \\
\text { expression in tumors vs. normal epithelia }\end{array}$ & - & $\begin{array}{l}\text { Poor differentiation, intra-and } \\
\text { extra hepatic metastases }\end{array}$ & [92] \\
\hline
\end{tabular}




\begin{tabular}{|c|c|c|c|c|c|c|c|c|}
\hline & 37 & $\begin{array}{l}\text { Surgical } \\
\text { resection }\end{array}$ & ACA & $\begin{array}{l}\text { Epithelial } \\
\text { (IHC) }\end{array}$ & $\begin{array}{l}(\downarrow) \text { in tumors vs. non-neoplastic liver, }(\downarrow) \\
\text { in poor differentiated tumors vs. well } \\
\text { differentiated }(\mathbf{p}<0.01)\end{array}$ & 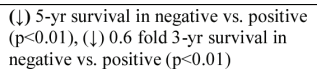 & $\begin{array}{l}\text { Poor histological } \\
\text { differentiation, lymph node } \\
\text { metastases }\end{array}$ & [34] \\
\hline \multirow[t]{2}{*}{ Lung } & $\begin{array}{l}184 \text { vs. } 100 \\
\text { controls }\end{array}$ & $\begin{array}{l}\text { Untreated } \\
\text { diagnostic } \\
\text { biopsy, } \\
\text { serum }\end{array}$ & $\begin{array}{l}\text { NSCLC and } \\
\text { SCLC }\end{array}$ & $\begin{array}{l}\text { Soluble } \\
\text { (ELISA) }\end{array}$ & $\begin{array}{l}(\uparrow) 2.5 \text { fold in tumors vs. normal controls } \\
(\mathrm{p}<0.0001)\end{array}$ & $\begin{array}{l}(\downarrow) \sim 2 \text {-fold months survival in higher } \\
\text { vs. lower expression than median } \\
\text { (median= } 41 \mathrm{ng} / \mathrm{ml}, \mathrm{p}=0.0030 \text { ) }\end{array}$ & $\begin{array}{l}\text { Large tumor mass, advanced } \\
\text { cancer }\end{array}$ & [93] \\
\hline & 116 & $\begin{array}{l}\text { Surgical } \\
\text { resection }\end{array}$ & SCLC & $\begin{array}{l}\text { Epithelial } \\
\text { (IHC) }\end{array}$ & $\begin{array}{l}\text { ( } \downarrow \text { ) in poor differentiated tumors }(22 \%, \\
\text { cutoff: }<10 \% \text { positive cells) vs. well } \\
\text { differentiated }(63 \%, p=.001)\end{array}$ & 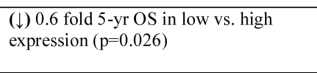 & Poorly differentiated & [94] \\
\hline \multirow[t]{2}{*}{ Mesothelioma } & $\begin{array}{l}\text { Pleural } \\
\text { effusions: } 163 \\
\text { vs. } 93 \text { benign; } \\
\text { sera: } 165 \text { vs. } \\
66 \text { benign }\end{array}$ & $\begin{array}{l}\text { Untreated } \\
\text { pleural } \\
\text { effusion and } \\
\text { serum }\end{array}$ & - & $\begin{array}{l}\text { Soluble } \\
\text { (ELISA) }\end{array}$ & $\begin{array}{l}\text { ( } \uparrow \text { in malignant pleural effusion vs. } \\
\text { control }(\mathrm{p}<0.0001) \text {. No significant } \\
\text { difference in sera }\end{array}$ & 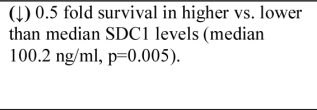 & Metastases & [164] \\
\hline & $\begin{array}{l}20,57 \text { (other } \\
\text { cancers), } 20 \\
\text { controls }\end{array}$ & $\begin{array}{l}\text { Tissue } \\
\text { blocks }\end{array}$ & $\begin{array}{l}\text { Epithelial, } \\
\text { biphasic, } \\
\text { sarcomatoid } \\
\text { mesothelioma }\end{array}$ & $\begin{array}{l}\text { Epithelial } \\
\text { (IHC) }\end{array}$ & $(\downarrow)$ in cancer vs. controls & $\begin{array}{l}\text { ( } \downarrow \text { ) survival in low }(<25 \% \\
\text { immunoreactivity) vs. high expression } \\
(\mathrm{p}=.033)\end{array}$ & - & [95] \\
\hline Nasopharyngeal & 68 & $\begin{array}{l}\text { Untreated } \\
\text { biopsy }\end{array}$ & & $\begin{array}{l}\text { Epithelial } \\
\text { (IHC) }\end{array}$ & $\begin{array}{l}21 \% \text { tumors positive }(>50 \% \text { cells }) \text { and } \\
52 \% \text { negative }(<10 \% \text { cells })\end{array}$ & 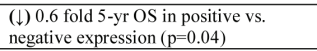 & - & [96] \\
\hline \multirow[t]{5}{*}{ Oral } & \multirow[t]{2}{*}{79} & \multirow[t]{2}{*}{$\begin{array}{l}\text { Archived } \\
\text { tissues }\end{array}$} & \multirow[t]{2}{*}{$\begin{array}{l}\text { Ameloblastomas, } \\
\text { KCOT, } \\
\text { dentigerous cysts }\end{array}$} & Epithelial & $\begin{array}{l}\text { (\) in ameloblastomas }(26.3 \%) \text { vs. KCOT } \\
(92.3 \%) \text {, dentigerous cysts }(100 \%)\end{array}$ & - & \multirow[t]{2}{*}{$\begin{array}{l}\text { Lesions' extension, } \\
\text { involvement of adjacent } \\
\text { structures }\end{array}$} & \multirow[t]{2}{*}{ [98] } \\
\hline & & & & $\begin{array}{l}\text { Stromal } \\
(\mathrm{IHC})\end{array}$ & No significant difference & & & \\
\hline & 72 & $\begin{array}{l}\text { Untreated } \\
\text { biopsy }\end{array}$ & SCC & Epithelial & $\begin{array}{l}9.7 \% \text { tumors showed strong staining, } \\
50 \% \text { weak or negative staining vs. strong } \\
\text { staining in normal epithelium }\end{array}$ & 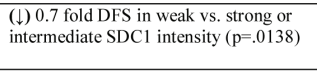 & $\begin{array}{l}\text { Nodal metastasis, } \\
\text { differentiation, IFG score }\end{array}$ & [100] \\
\hline & \multirow[t]{2}{*}{39} & \multirow{2}{*}{$\begin{array}{l}\text { Untreated } \\
\text { biopsy } \\
\text { excision }\end{array}$} & \multirow[t]{2}{*}{ SCC } & $\begin{array}{l}\text { Epithelial } \\
\text { (IHC) }\end{array}$ & $\begin{array}{l}\text { (\) in tumors vs. controls (strong } \\
\text { intensity in } 15.4 \% \text { patients, weak in } 2 \% \text { ) }\end{array}$ & - & \multirow[t]{2}{*}{$\begin{array}{l}\text { Recurrent events, rapid tumor } \\
\text { progression }\end{array}$} & \multirow[t]{2}{*}{ [101] } \\
\hline & & & & $\begin{array}{l}\text { Stromal } \\
\text { (IHC) }\end{array}$ & $(\uparrow)$ in tumors vs. normal epithelium & 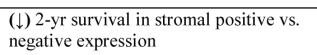 & & \\
\hline \multirow[t]{3}{*}{ Ovarian } & \multirow[t]{2}{*}{111} & \multirow[t]{2}{*}{ Surgical } & \multirow[t]{2}{*}{ ACA } & $\begin{array}{l}\text { Epithelial } \\
\text { (IHC) }\end{array}$ & $\begin{array}{l}\text { ( }) \text { in advanced stage tumors vs. early } \\
\text { stage }(p=0.01)\end{array}$ & $\begin{array}{l}(\downarrow) \text { estimated } 5 \text {-yr PFS }(\mathrm{p}=0.025) \text { in } \\
\text { negative vs. positive epithelial SDC1 }\end{array}$ & Advanced stage & \multirow[t]{2}{*}{ [103] } \\
\hline & & & & $\begin{array}{l}\text { Stromal } \\
\text { (IHC) }\end{array}$ & $\begin{array}{l}(\uparrow) \text { in advanced stage vs. early stage } \\
\text { tumors }(p<0.0001)\end{array}$ & $\begin{array}{l}(\downarrow) \text { estimated } 5 \text {-yr PFS }(\mathrm{p}=0.001) \text {; OS } \\
(\mathrm{p}=0.022) \text { in high vs. low stromal } \\
\text { expression }\end{array}$ & $\begin{array}{l}\text { Histological subtype, massive } \\
\text { ascites, lymph node } \\
\text { metastasis }\end{array}$ & \\
\hline & $\begin{array}{l}115 \text { vs. } 10 \\
\text { borderline, } 10 \\
\text { benign, } 12 \\
\text { controls }\end{array}$ & $\begin{array}{l}\text { Archived } \\
\text { surgical }\end{array}$ & $\mathrm{ACA}$ & $\begin{array}{l}\begin{array}{l}\text { Stromal } \\
\text { (IHC) }\end{array} \\
\end{array}$ & $\begin{array}{l}\text { Positive expression in tumors vs. absent } \\
\text { in normal ovaries }\end{array}$ & 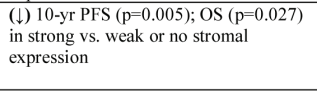 & Advanced stage & [104] \\
\hline \multirow[t]{2}{*}{ Pancreatic } & \multirow[t]{2}{*}{$\begin{array}{l}144 \text { vs. } 18 \\
\text { pancreatitis, } 4 \\
\text { controls }\end{array}$} & \multirow[t]{2}{*}{ Surgical } & \multirow[t]{2}{*}{ Ductal ACA } & $\begin{array}{l}\text { Epithelial } \\
\text { (IHC) }\end{array}$ & $94 \%$ tumors positive (cutoff: $>20 \%$ ) & \multirow{2}{*}{$\begin{array}{l}(\downarrow) 0.2 \text { fold cumulative survival in } \\
\text { stromal+/epithelial- vs. stromal- } \\
\text { /epithelial+ and other patients } \\
(\mathrm{p}=0.003)\end{array}$} & \multirow[t]{2}{*}{$\begin{array}{l}\text { Epithelial: better prognosis } \\
\text { Stromal:histological grade, } \\
\text { tumor location }\end{array}$} & \multirow[t]{2}{*}{ [105] } \\
\hline & & & & $\begin{array}{l}\text { Stromal } \\
\text { (IHC) }\end{array}$ & $\begin{array}{l}(\uparrow) \text { in tumors vs. acute and chronic } \\
\text { pancreatitis samples }\end{array}$ & & & \\
\hline \multirow[t]{3}{*}{ Prostate } & $\begin{array}{l}60 \mathrm{vs} .10 \\
\text { controls }\end{array}$ & Surgical & Localized & $\begin{array}{l}\text { Epithelial } \\
\text { (IHC) }\end{array}$ & $\begin{array}{l}\text { ( } \downarrow) \text { membranous and }(\uparrow) \text { cytoplasmic } \\
(64 \% \text { tumors) vs. benign prostatic } \\
\text { hyperplasia, tonsil cancer samples }\end{array}$ & $\begin{array}{l}\text { ( } \downarrow) \text { PSA-RFS in altered vs. normal } \\
\text { SDC1 expression }(p<0.05)\end{array}$ & High Gleason score & [106] \\
\hline & 232 & $\begin{array}{l}\text { Untreated } \\
\text { surgical }\end{array}$ & Localized & $\begin{array}{l}\text { Epithelial } \\
\text { (IHC) }\end{array}$ & $\begin{array}{l}(\uparrow) \text { cells expressing SDC1 ( } 37.1 \% \text { tumors } \\
\text { positive) vs. normal adjacent and benign } \\
\text { prostatic basal cells }\end{array}$ & $\begin{array}{l}\text { ( } \downarrow \text { ) PSA-PFS in positive vs. negative } \\
\text { expression }(p=0.034)\end{array}$ & $\begin{array}{l}\text { Higher PSA levels, lymph } \\
\text { nodes metastases }\end{array}$ & [107] \\
\hline & $\begin{array}{l}551 \text { vs. } 83 \\
\text { controls }\end{array}$ & Surgical & Localized & $\begin{array}{l}\text { Epithelial } \\
\text { (IHC) }\end{array}$ & $\begin{array}{l}\text { ( } \uparrow \text { in } 36.7 \% \text { tumors positive vs. } 22.9 \% \\
\text { controls }\end{array}$ & $\begin{array}{l}\text { ( } \downarrow) \text { time to progression }(\mathrm{p}<0.02) \text {, tumor } \\
\text { specific survival }(\mathrm{p}<0.01), \mathrm{OS}(\mathrm{p}=0.07) \\
\text { in positive vs. negative expression }\end{array}$ & High Gleason grade & [109] \\
\hline \multirow[t]{2}{*}{ Thyroid } & \multirow[t]{2}{*}{62} & \multirow[t]{2}{*}{ Surgical } & \multirow[t]{2}{*}{ PCT } & $\begin{array}{l}\text { Epithelial } \\
\text { (IHC) }\end{array}$ & Strong in PCT-E vs. PCT-NE $(\mathrm{p}=.002)$ & \multirow[t]{2}{*}{-} & \multirow[t]{2}{*}{$\begin{array}{l}\text { Extracapsular invasion, tumor } \\
\text { progression. }\end{array}$} & \multirow[t]{2}{*}{ [165] } \\
\hline & & & & $\begin{array}{l}\text { stromal } \\
\text { (IHC) }\end{array}$ & Strong in PCT-E vs. PCT-NE $(\mathrm{p}=.048)$ & & & \\
\hline
\end{tabular}

chondroitin sulfate (CS) chains present in syndecan is not completely understood. A study by Okamoto and colleagues suggested a cooperative role of CS chains with HS chains in binding to the extracellular matrix protein laminin [23]. Although HS chains are major contributors to the function of syndecan, recent studies have revealed that the protein core ectodomains are also engaged in protein-protein interactions between syndecan and other peptide molecules [24, 25]. On the intracellular side, the cytoplasmic domain binds to several cytoskeletal proteins, such as ezrin, tubulin, and cortactin, which potentiates cell anchorage and stabilizes cell morphology [6-8]. Thus, syndecan plays an important role in the interplay between target cells and the extracellular matrix. Among the different syndecans, SDC1 was first to be identified and evaluated and is implicated in the maintenance of epithelial morphology and anchorage-dependent growth $[26,27]$.

\section{Shed/Soluble syndecan}

Syndecan can be proteolytically cleaved at a juxtamembrane site, which releases the extracellular (ectodomain) core protein bearing both HS and CS chains (Figure 1C) [28]. Cells constitutively shed syndecan at low levels, but shedding is accelerated in response to growth factors, chemokines, heparanase, microbial toxins, insulin, and cellular stress [29, 30]. These stimuli trigger several signaling pathways that eventually lead to elevated protease activity driving syndecan shedding. The syndecan molecules that are shed remain biologically active and can bind the same ligands as the intact ectodomain. Accordingly, shed syndecan may act in a paracrine manner [31]. On the other hand, shed ectodomains may compete for the same ligand as the surface receptor (acting as decoy receptors), thus downregulating signal transduction (Figure 1C) [31]. 
Table 2: Studies evaluating SDC1 as a prognostic biomarker in cancer patients with hematological tumors.

\begin{tabular}{|c|c|c|c|c|c|c|c|c|}
\hline Cancer Type & $\begin{array}{l}\text { Patient } \\
\text { Number }\end{array}$ & Specimen Type & $\begin{array}{l}\text { Cancer } \\
\text { Subtype }\end{array}$ & $\begin{array}{l}\text { Location } \\
\text { (Method) }\end{array}$ & SDC1 Expression Pattern & Prognosis & Associated with & Ref \\
\hline $\begin{array}{l}\text { Chronic } \\
\text { lymphocytic } \\
\text { leukemia }\end{array}$ & $\begin{array}{l}104 \text { vs. } 32 \\
\text { controls }\end{array}$ & $\begin{array}{l}\text { Blood and BM } \\
\text { samples }\end{array}$ & - & $\begin{array}{l}\text { Soluble } \\
\text { (ELISA) }\end{array}$ & $(\uparrow)$ in tumors vs. controls & $\begin{array}{l}\text { (๖) } 0.6 \text { fold } O S \text { in high }(>53 \mathrm{ng} / \mathrm{ml}) \text { vs. low } \\
(<53 \mathrm{ng} / \mathrm{ml}) \text { serum SDC1 level }(\mathrm{p}=0.0004)\end{array}$ & No significant correlation & [112] \\
\hline \multirow[t]{2}{*}{$\begin{array}{l}\text { Diffuse large B- } \\
\text { cell lymphoma }\end{array}$} & 46 & Untreated biopsy & $\begin{array}{l}\text { Nodal, } \\
\text { extra-nodal }\end{array}$ & $\begin{array}{l}\text { Epithelial } \\
\text { (IHC) }\end{array}$ & Positive in $39 \%$ tumors & 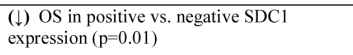 & - & [114] \\
\hline & 51 & TMA blocks & $\begin{array}{l}\text { Nodal, } \\
\text { tonsillar }\end{array}$ & $\begin{array}{l}\text { Epithelial } \\
\text { (IHC) }\end{array}$ & Positive in $15.7 \%$ tumors & $\begin{array}{l}\text { ( } \downarrow) \text { OS in positive vs. negative SDC1 } \\
\text { expression ( } \mathrm{p}=0.0008)\end{array}$ & - & [113] \\
\hline \multirow[t]{2}{*}{$\begin{array}{l}\text { Hodgkin's } \\
\text { lymphoma }\end{array}$} & 25 & Blood, tissue blocks & NS & $\begin{array}{l}\text { Epithelial } \\
\text { (IHC) }\end{array}$ & $\begin{array}{l}(\uparrow) \text { in HL tumors vs. NHL and normal } \\
\text { lymph nodes, } 56 \text {-fold increase in poor } \\
\text { vs. good outcome }\end{array}$ & Poor outcome & - & [138] \\
\hline & 66 & Untreated serum & $\begin{array}{l}\text { NS, MC, } \\
\text { LP }\end{array}$ & $\begin{array}{l}\text { Soluble } \\
\text { (ELISA) }\end{array}$ & $\begin{array}{l}(\uparrow) \sim 1.5 \text {-fold in HL } v s . \mathrm{NHL} \text { and } \\
\text { lymph node controls }(\mathrm{p}<0.001)\end{array}$ & No significant difference & $\begin{array}{l}\text { Age, gender, elevated B2M } \\
\text { and IPS }\end{array}$ & [124] \\
\hline \multirow[t]{7}{*}{$\begin{array}{l}\text { Multiple } \\
\text { myeloma }\end{array}$} & $\begin{array}{l}17 \mathrm{MM}, 14 \\
\text { MGUS }\end{array}$ & Serum & - & $\begin{array}{l}\text { Soluble } \\
\text { (ELISA) }\end{array}$ & $\begin{array}{l}(\uparrow) \sim 48 \text {-fold in MM tumors vs. MGUS } \\
(\mathrm{p}<0.001)\end{array}$ & $\begin{array}{l}(\downarrow) \text { OS in high }(>500 \mathrm{ng} / \mathrm{ml}) \text { vs. low }(<500 \\
\mathrm{ng} / \mathrm{ml}) \text { level }(\mathrm{p}=0.029)\end{array}$ & - & [119] \\
\hline & 478 & Serum & - & $\begin{array}{l}\begin{array}{l}\text { Soluble } \\
\text { (ELISA) }\end{array}\end{array}$ & $\begin{array}{l}\text { ( } \uparrow \sim 1.7 \text {-fold in presentation phase vs. } \\
\text { plateau phase patients }\end{array}$ & $\begin{array}{l}(\downarrow) 0.7 \text { and } 0.5 \text { fold years survival in high } \\
(>960 \mathrm{ng} / \mathrm{ml}) \mathrm{vs} . \text { low }(<196 \mathrm{ng} / \mathrm{ml}) \text { level; } \\
(\mathrm{p}=0.0006)\end{array}$ & $\begin{array}{l}\text { Monoclonal paraprotein, } \\
\text { B2M, BM plasma cell } \\
\text { content }\end{array}$ & [56] \\
\hline & 67 & $\begin{array}{l}\text { Untreated blood, BM } \\
\text { aspirates or biopsy }\end{array}$ & - & $\begin{array}{l}\begin{array}{l}\text { Soluble } \\
\text { (ELISA) }\end{array}\end{array}$ & $\begin{array}{l}(\uparrow) \sim 13 \text {-fold in tumors vs. controls }(p \\
<0.0001) ;(\uparrow) 2 \text { fold in BM vs. blood } \\
(\mathrm{p}<0.0001)\end{array}$ & $\begin{array}{l}(\downarrow) 0.7 \text { fold } \text { OS in high }(>225 \mathrm{ng} / \mathrm{ml}) \text { vs. low } \\
(<225 \mathrm{ng} / \mathrm{ml})(\mathrm{p}=0.039)\end{array}$ & Microvessel density & [121] \\
\hline & $\begin{array}{l}32 \text { vs. } 11 \\
\text { controls }\end{array}$ & $\begin{array}{l}\text { Untreated, post } \\
\text { remission serum }\end{array}$ & - & $\begin{array}{l}\text { Soluble } \\
\text { (ELISA) }\end{array}$ & $\begin{array}{l}(\uparrow) \text { in pretreatment serum }(\mathrm{p}=0.001) \\
\text { and }(\downarrow) \text { in treated subjects vs. healthy } \\
\text { controls }\end{array}$ & 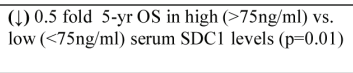 & Stage and B2M & [122] \\
\hline & \multirow[t]{2}{*}{$\begin{array}{l}25 \text { vs. } 10 \\
\text { controls }\end{array}$} & \multirow[t]{2}{*}{$\begin{array}{l}\text { Untreated and treated } \\
\text { serum }\end{array}$} & \multirow[t]{2}{*}{ - } & $\begin{array}{l}\text { Epithelial } \\
\text { (FCM) }\end{array}$ & $\begin{array}{l}(\uparrow) \text { responders and survivors vs. } \\
\text { nonresponders and nonsurvivors }(\mathrm{P}< \\
0.01 \text { ) }\end{array}$ & $\begin{array}{l}\text { ( } \downarrow \text { ) survival in low vs. high cellular } \\
\text { expression ( } \mathrm{p}<0.01 \text { ) }\end{array}$ & \multirow{2}{*}{$\begin{array}{l}\text { Inversely: with stage; } \\
\text { directly: with plasma cell } \\
\text { count, B2M, serum } \\
\text { creatinine, CRP, AP and } \\
\text { serum calcium }\end{array}$} & \multirow[t]{2}{*}{116} \\
\hline & & & & $\begin{array}{l}\text { Soluble } \\
\text { (ELISA) }\end{array}$ & $\begin{array}{l}(\uparrow) \sim 9 \text {-fold in tumors vs. controls }(\mathrm{p} \\
<0.001) \text {, high in non-responders and } \\
\text { non-survivors }\end{array}$ & $\begin{array}{l}\text { (๖) survival in high vs. low serum SDC1 } \\
\text { levels }(\mathrm{p}<0.001)\end{array}$ & & \\
\hline & $\begin{array}{l}35 \text { vs. } 21 \\
\text { (other } \\
\text { diseases), } 14 \\
\text { controls }\end{array}$ & $\begin{array}{l}\text { Untreated BM } \\
\text { aspirates }\end{array}$ & - & $\begin{array}{l}\text { Soluble } \\
\text { (ELISA) }\end{array}$ & $\begin{array}{l}(\uparrow)>2 \text {-fold in cancer vs. other } \\
\text { diseases subjects }(p>0.002) \text { and } \\
\text { healthy controls }(p>0.001)\end{array}$ & - & HGF & [117] \\
\hline
\end{tabular}

AP: alkaline phosphatase; Beta-2 microglobulin (B2M); BM: bone marrow; CRP: C-reactive protein; DLBCL: diffuse large B cell lymphoma; FCM: flow cytometry; HGF: hepatocyte growth factor; IHC: immunohistochemistry; IPS: International Prognostic score; LP: lymphocyte predominance; MGUS: monoclonal gammopathy of undetermined significance; MC: mixed cellularity; MM: multiple myeloma; NHLNon-Hodgkin Lymphoma; NS: Nodular sclerosis; OS: overall survival; SDC1: syndecan-1; TMA: tissue microarray.

\section{Syndecan in Cancer}

The expression of SDC1 is dysregulated in cancer, and low expression of SDC1 in epithelial cells is associated with poor prognosis and high metastatic potential [32-34]. Tables 1 and 2 summarize the studies to date that have evaluated SDC1 prognostic significance and clinical implications in solid and hematological tumors, respectively.

Studies have shown that SDC1 is involved in multiple cellular processes, including cell proliferation [24, 39-41], migration [42-44], adhesion, and angiogenesis [30, 45].In general, the loss of SDC1 expression in carcinoma cells reduces cell adhesion to the extracellular matrix and enhances cell motility and invasion [15]. Alternatively, increased stromal SDC1 expression alters fibronectin production and extracellular matrix organization [35]. In addition, increased expression of SDC1 in stromal fibroblasts is associated with angiogenesis and cancer progression $[15,36]$. Various signaling molecules function upstream or downstream from SDC1 in cancer (examples are listed in Table 3). SDC1 acts as a scaffold that brings ligands, such as hepatocyte growth factor (HGF), bFGF/ FGF2, and VEGF, in close proximity to their cognate receptors. This localization activates downstream signal transduction pathways, such as the "PI3K to Akt" and "Ras to MAPK" pathways, which enhances the proliferation of endothelial cells, cancer cells, and fibroblasts (Figure 1B) $[15,37]$. For example, the binding of HGF with SDC1 enhances downstream signaling in myeloma cells, osteoblasts, and stromal cells $[15,38]$. SDC activates integrin $\alpha v \beta$ [46] and Wnt5a [47] signaling in breast cancer and multiple myeloma, respectively (Table 3). SDC increases cell adhesion via activation of focal adhesion kinase (FAK) signaling in lung and colorectal cancers [48, 49]. Mulitple molecules such as ADAM-10, ADAM-17, MMP-7, MMP-9, MMP-14, and bFGF/FGF2 increase $\mathrm{SDC} 1$ shedding in multiple myeloma as well as breast and colon cancers [50-54] (Table 3).

Alterations in the levels of soluble SDC1 have been reported in various cancer types. The levels of soluble SDC1 in the sera of healthy persons are relatively low compared to levels in cancer patients. Heparanase induces SDC1 shedding, and soluble SDC1 is an independent negative prognostic factor in multiple myeloma [32, 55, 56]. High levels of heparanase have also been reported in the plasma of Hodgkin's lymphoma (HL) patients and it can be used to evaluate treatment response [57]. Soluble SDC1 is biologically active and can intensify the binding between growth factors with their receptors in tumor stroma $[30,58]$. Soluble SDC1 ectodomains bind to pro-angiogenic factors, which promotes endothelial cell invasion (Figure 1C) [30]. Soluble SDC1 also increases fibroblast proliferation and the release of TGF- $\beta$ [58]. In addition, soluble SDC1 can act as decoy receptor, and thus it may promote cancer progression by sequestering inhibitory molecules (Figure 1C) [59].

Many reports indicate that Heparan Sulfate Proteoglycans (HSPGs) may localize to the nucleus [60, 61]. A recent study showed that SDC1 is present in the nucleus of myeloma tumor cells where it activates gene transcription (Figure 1D) [62]. In addition, shed SDC1 
Table 3: Examples of proteins associated with the SDC pathway in cancer.

\begin{tabular}{|c|c|c|c|c|c|}
\hline Protein & Association & $\begin{array}{l}\text { Level of } \\
\text { Interaction }\end{array}$ & Cancer & Pathway & Ref \\
\hline ADAM10, ADAM17 & ADAM10 and ADAM17 contribute to SDC1 shedding by HVECs in response to TSST-1 & Upstream & Multiple myeloma & TSST-1 & [50] \\
\hline \multirow{2}{*}{$\alpha v \beta 3$} & $\mathrm{SDC1}$ increases $\alpha v \beta 3$ integrin activation and signaling & Upstream & Breast cancer & avß3 integrin & [46] \\
\hline & $\begin{array}{l}\text { av } 33 \text { integrin forms a complex with extracellular domain of SDC1 which promotes docking of IGFR with } \\
\text { SDC1 ectodomain }\end{array}$ & Upstream & Breast cancer & avß3 integrin & [166] \\
\hline BCL-2 & $\begin{array}{l}\text { SHH signaling enhanced SDC }+ \text { cell proliferation and activated BCL-2, leading to the inhibition of cancer } \\
\text { cell apoptosis }\end{array}$ & Upstream & Multiple myeloma & Hedgehog & [167] \\
\hline bFGF & bFGF increases SDC1 shedding, and SDC1 induces bFGF signaling & Upstream & Pancreatic cancer & FGFR & {$[54,133,134]$} \\
\hline CASK & SDC2 and 3 associate via their C-terminal binding motif with CASK & Downstream & Breast cancer & Cask signaling & {$[168]$} \\
\hline FAK & $\begin{array}{l}\text { Cancer cells contact with fibronectin leads to SDC2 upregulation and increase in cell adhesion via FAK } \\
\text { signaling }\end{array}$ & Downstream & Colorectal cancer & FAK & [49] \\
\hline Fibronectin & $\begin{array}{l}\text { The trimeric Tn antigen on SDC1 enhances integrin } \alpha 5 \beta 1 \text { functions, resulting in increased adhesion to } \\
\text { fibronectin via the FAK/paxillin pathway }\end{array}$ & Upstream & Lung cancer & FAK & [48] \\
\hline IGFIR & $\begin{array}{l}\text { IGF1R, avB3 integrin and SDC1 form a ternary receptor complex in which signaling downstream of IGFIR } \\
\text { activates av } 33 \text { integrin }\end{array}$ & Upstream & Breast cancer & IGF1R & [139] \\
\hline KRAS & SDC2 cooperates with KRAS to induce an invasive phenotype & Downstream & Pancreatic cancer & KRAS /MAPK & [169] \\
\hline MMP-7 & SDC2 elevates MMP-7 expression, and MMP-7 increases SDC2 shedding & Downstream & Colon cancer & Wnt & [51] \\
\hline MMP-9 & Increased expression of MMP-9 lead to increased shedding of SDC1 & Upstream & Multiple myeloma & ERK Signaling & {$[52]$} \\
\hline $\begin{array}{l}\text { MT1-MMP (MMP- } \\
\text { 14) }\end{array}$ & $\begin{array}{l}\text { MT1-MMP expressed by stromal fibroblasts cleaves SDC1 and releases SDC1 ectodomain as a paracrine } \\
\text { mediator }\end{array}$ & Upstream & Breast cancer & Multiple & [53] \\
\hline VEGFR & Shed SDC1 forms a complex with VEGF which activates VEGFR receptors & Upstream & Multiple myeloma & VEGFR & {$[30]$} \\
\hline Wnt5a & SDC1 and SDC4 increase Wnt5 A signaling and cellular invasion & Downstream & Multiple myeloma & Wnt & [47] \\
\hline
\end{tabular}

ADAM: A disintegrin and metalloproteinase domain-containing protein; $\alpha v \beta 3$ : alpha-v beta-3; BCL-2: B-cell lymphoma 2 protein; bFGF: basic fibroblast growth factor; CASK: calcium/calmodulin-dependent serine kinase; FAK: focal adhesion kinase; HVECs: human vaginal epithelial cells; IGF1R: insulin-like growth factor-1 receptor; MMP: matrix metallopeptidase; MT1-MMP: membrane type 1 matrix metalloproteinase; SDC: syndecan; SHH: hedgehog signaling pathway; TSST-1: toxic shock syndrome toxin-1; VEGFR: vascular endothelial growth factor receptor

can localize to the nucleus in areas involved in gene transcription [63].

\section{Syndecan as a prognostic biomarker in solid tumors}

\section{Bladder cancer}

High SDC1 expression was observed in over $60 \%$ of specimens from patients diagnosed with primary non-muscle-invasive bladder cancer, and SDC1 was a significant predictor for recurrence-free survival [64]. In addition, SDC1 was found to be expressed on the cell membrane of normal bladder epithelium and non-muscleinvasive bladder cancer cells, but was almost completely absent in muscle-invasive carcinomas [65]. In contrast, stromal SDC1 as well as serum SDC1 levels were higher in muscle-invasive compared to non-muscle-invasive bladder cancer cells. Lymph node-positive cases had the highest SDC1 serum concentrations, and SDC1 expression in stromal cells was independently associated with survival. Loss of SDC1 in tumor cells and the simultaneous increase of serum SDC1 levels in high-stage, high-grade bladder cancer cells suggest that SDC1 shedding is associated with bladder cancer cell aggressiveness [65]. Thus, circulating levels of SDC1 may ultimately be a useful prognostic tool for identifying patients with lymph node metastases [65].

Assessing urinary SDC1 levels and tumor SDC1 expression revealed no significant difference in urinary SDC1 levels between cancer and healthy subjects [67]. However, urinary levels of SDC1 were reduced in highgrade disease compared to low-grade disease states [66]. Interestingly, SDC1 predominantly localized to the cell membrane in normal tissue and low-grade tumors, while high-grade tumors exhibited distinct cytoplasmic localization. In these reports, the tumor stage and grade can change the value of urinary and serum levels of SDC1 as prognostic tools in urinary bladder cancers.
However, localization of SDC1 in the membranous or cytoplasmic compartments may correlate with the stage and aggressiveness of urinary bladder cancers.

\section{Breast cancer}

SDC1 has been shown to be expressed at high levels in breast cancer specimens and was associated with high histologic grade, large tumor size, high mitotic count, and poor prognosis [67]. High SDC1 levels were also associated with a higher risk of death in patients treated with the cyclophosphamide-methotrexate-fluorouracil chemotherapeutic regimen [67]. High SDC1 expression was reported in triple-negative invasive ductal breast carcinomas compared to normal breast tissue [68]. SDC1 expression was also strongly correlated with patient overall survival [68]. Evaluation of SDC1 expression in invasive ductal carcinoma indicated that cytoplasmic expression of SDC1 was positively correlated with WNT1 (a proto-oncogene) and membranous expression of SDC1 was positively correlated with p16 (a tumorsuppressor protein) [69]. Another study found that SDC1 expression was significantly increased in invasive breast cancer cases, suggesting that it may serve as a useful prognostic biomarker for aggressive breast cancer [33]. A tissue microarray of invasive ductal breast carcinoma specimens indicated high expression of SDC1 in the breast epithelium of more than half of the patients, whereas stromal expression was observed in only one third of the patients. Moreover, a significant correlation was found between the loss of epithelial SDC1 expression in highgrade tumors. These findings suggest that lack of SDC1 epithelial expression is a strong prognostic marker in breast carcinomas [70]. Tiemann and colleagues studied the role of SDC1 in ductal carcinoma in situ of the breast (DCIS) [71]. Tumor grade was found to be related to the proportion of SDC1-positive cells, rather than to the intensity of SDC1 staining. In the same study, estrogen receptor (ER) expression did not affect the staining intensity of SDC1, but negatively correlated with the 
percentage of SDC1-positive cells. Further findings showed that expression of progesterone receptor (PR) was positively influenced by both the intensity of staining and the percentage of SDC1-positive cells. These results suggest a potential role of SDC1 in the pathogenesis of DCIS [71]. Additional studies compared expression of SDC1 in breast cancer cases with and without distant organ metastasis. SDC1 expression was significantly correlated with a higher histological grade. In addition, HER2 subtype and triple-negative carcinomas showed significantly higher SDC1 levels than those of control cases. Importantly, high SDC1 expression had a negative impact on both overall and disease-free survival rates [72].

In another study, SDC1 expression was detected in approximately $70 \%$ of breast cancer cases and found to correlate with tumor grade. The presence of SDC1 in high-grade tumors was associated with the absence of SDC4 [73]. Further evidence indicated strong staining of SDC1 in DCIS tumor samples, which was associated with E-cadherin and c-Met expression [46]. In addition, expression of SDC1 and SDC4 was correlated with the $\mathrm{Ki}-67$ mitosis index, suggesting a role in breast cancer cell proliferation. In addition, SDC1 and SDC4 expression was correlated with negative ER status and aggressive phenotypes [74]. Strong SDC1 staining was observed in more than $80 \%$ of neoplastic cells and was associated with increased mortality risk. In addition, there was a strong negative correlation between SDC1 expression and extracellular matrix proteins, suggesting that SDC1 promotes tumor progression by interacting with extracellular matrix components and impacting breast cancer tissue remodeling [75]. In another study, the expression of SDC1 was equivalent in the epithelium and stroma of breast tumors, but epithelial SDC1 expression was associated with negative ER status while stromal SDC1 expression was associated with positive ER status [76]. Moreover, loss of epithelial or stromal SDC1 expression was associated with a more favorable 10-year overall survival rate [76]. These findings indicate that SDC1 is expressed at high levels in breast cancer and its expression is associated with aggressive phenotypes and poor clinical outcomes.

\section{Cervical cancer}

Most cervical cancer tissues assessed to date have been shown to be SDC1-positive, and localization of SDC1 in the cytoplasm was associated with better patient survival. In addition, the change of SDC1 expression in cervical cancers was not caused by copy number alteration of the gene [77]. The progression of cervical intraepithelial neoplasm to early invasive cancer was found to correlate with reduced levels of SDC1 [78]. In another study, biopsies obtained from patients treated for primary invasive cervical carcinoma showed that SDC1 expression is associated with histological differentiation grade and squamous histology, but the expression does not predict clinical outcome [79].

\section{Colorectal cancer}

Recent reports have indicated that colorectal patients have higher serum levels of soluble SDC1 compared to healthy adults, which correlates with poor survival [80]. Patients with high SDC1 serum levels were also less responsive to 5-fluorouracil, oxaliplatin, irinotecan, cisplatin, or paclitaxel chemotherapy treatments [80]. Further studies revealed that SDC1 is expressed at the basolateral borders of normal colonic epithelial cells; however, in adenocarcinoma cells, SDC1 was found to be present around epithelial cell membranes and in the cytoplasm [81]. In approximately $90 \%$ of adenocarcinomas examined, SDC1 expression was absent, and this correlated with lymph node metastasis. Stromal SDC1 was expressed in a small fraction of tumors. These findings emphasize that the loss of tumor SDC1 may be a potential prognostic biomarker for human colon adenocarcinomas [81]. In another study, the expression of epithelial SDC1 was observed in over $90 \%$ of colorectal cancer specimens and was associated with lower histological grade and a less advanced clinical stage [82]. Expression of stromal SDC1 was observed in 58\% of specimens, but expression did not significantly correlate with clinical outcome [82]. Taken together, these studies indicate that SDC1 expression may be a useful biomarker for evaluating the stage and grade of colorectal tumors. The lack of consistency between studies may be related to patient selection or methodological differences, and therefore larger studies are needed to further evaluate the prognostic impact of SDC1 in patients with colorectal tumors.

\section{Endometrial cancer}

In endometrial cancer, epithelial SDC1 expression was significantly lower in advanced stage, high grade, and lymph node metastatic disease [83]. In contrast, stromal SDC1 expression was significantly higher in high-grade tumors [83]. Moreover, SDC1 expression was totally absent in poorly differentiated endometrial cancer tissues, while it was abundant in normal endometrial and highly differentiated malignant tissues [84].

\section{Gallbladder cancer}

Epithelial SDC1 was observed in approximately half of gallbladder cancer cases evaluated, and its expression was associated with lymph node metastasis. This study also found that patients with positive SDC1 expression had a significantly shorter survival time than patients with undetectable expression [85].

\section{Gastric cancer}

Loss of epithelial SDC1 expression as well as high stromal SDC1 expression was associated with unfavorable prognosis in gastric cancer [86]. Additional studies showed that loss of epithelial SDC1 expression 
was associated with high stromal SDC1 expression, higher tumor grade, poor overall survival, and nodal metastases [87]. Therefore, stromal and epithelial SDC1 expression might have some prognostic impact in gastric cancer. However, these findings are not consistent and require further investigation.

\section{Glioma}

Higher gene and protein levels of SDC1 were detected in glioma tissues compared to controls. Moreover, SDC1 expression was increased in high-grade tumors, and the overall survival rate of SDC1 positive patients was significantly lower than that of SDC1 negative patients [88].

\section{Laryngeal cancer}

SDC1 expression was detected in all laryngeal cancer specimens examined by Klatka and colleagues, and expression was significantly correlated with histological grade and patient survival rate [89]. Additional investigation indicated that tumors with intermediate or strong staining for SDC1 were associated with higher overall survival than tumors with no or low SDC1 expression [90].

\section{Liver cancer}

In patients with advanced hepatocellular carcinoma (HCC), serum levels of SDC1 were increased compared to those without HCC or with early HCC [91]. High serum SDC1 levels were significantly associated with greater risk of tumor recurrence and decreased overall survival in patients with early $\mathrm{HCC}$ and with advanced HCC, respectively [91]. Additional studies showed reduced expression of the SDC1 gene and protein in metastatic HCC patients compared to those with non-metastatic disease [92]. Thus, the loss of SDC1 expression could be a characteristic feature of $\mathrm{HCC}$ with high metastatic potential [92].

SDC1 protein and gene expression levels were also assessed in intrahepatic cholangiocarcinomas and normal bile duct epithelial cells [34]. Intrahepatic cholangiocarcinoma cells showed membranous and cytoplasmic expression of SDC1, while normal epithelial cells showed restricted basolateral membranous expression. In cancerous tissues, the distribution of SDC1 mRNA was similar to that of the protein, suggesting that $\mathrm{SDC} 1$ expression in intrahepatic cholangiocarcinoma is regulated at the transcriptional level. Moreover, loss of SDC1 expression in carcinoma was associated with poor differentiation and lymph node metastases [34].

\section{Lung cancer}

In lung cancer patients, high serum SDC1 and bFGF levels were associated with poor outcomes at the time of diagnosis [93]. In another study, evaluation of SDC1 expression in squamous cell lung carcinoma patients showed higher expression of SDC1 in well-differentiated cancers than in moderately or poorly differentiated tumors [94]. Cancers with high SDC1 expression were associated with more favorable overall survival, suggesting that loss of SDC1 expression occurs as a result of histological dedifferentiation and that low SDC1 expression is associated with unfavorable outcomes in squamous cell carcinoma of the lung [94].

\section{Mesothelioma}

Studies of the expression of SDC1 protein in mesothelioma tumors and cell lines revealed strong SDC1 expression in epithelial mesotheliomas and in epithelial components of biphasic mesotheliomas, while expression was reduced during sarcomatoid differentiation [95]. Moreover, SDC1 expression was associated with longer overall survival in patients with mesotheliomas compared to patients with no or low SDC1 expression [95]. In another study, SDC1 was detected in pleural effusions, but not in sera of patients with pleural metastatic disease and malignant mesothelioma [67]. These findings distinguish malignant and benign diseases and suggest that SDC1 expression levels may be a prognostic factor that can predict differences in survival [67].

\section{Nasopharyngeal carcinoma and oral cancer}

An analysis of SDC1 and c-Met in samples from nasopharyngeal carcinoma patients by immunohistochemical staining indicated that high coexpression of c-Met and SDC1 was adversely correlated with patient survival [96]. Normal oral mucosa has been shown to express moderate-to-high levels of SDC1, which is reduced or abolished in carcinomas [97]. In another study, SDC1 was found to be mainly expressed in the stromal cells, and this pattern was associated with poor prognosis of ameloblastomas, keratocystic odontogenic tumors [98]. SDC1 expression was significantly higher in normal controls than in specimens from patients with mild, moderate, or severe dysplasia as well as invasive squamous cell carcinoma; however, no significant difference was found between different tumor grades [99]. In another study, approximately $90 \%$ of oral squamous cell carcinoma cases showed negative or weak SDC1 staining. Patients with intermediate or strong staining intensity for SDC1 had a significantly better prognosis than patients with negative or weak staining intensity [100]. SDC1 expression was decreased in more than $80 \%$ of oral carcinoma cases examined, but positive stromal SDC1 staining proved to be a significant risk factor of recurrence and tumor-specific death within a 24-month period after surgery, suggesting stromal expression of SDC1 is a reliable indicator of an adverse prognosis in oral carcinomas [101]. In another study, SDC1 levels were increased in response to cytostatic treatment, which proved to be an important predictive factor and a clear forecast of a good prognosis [102]. Taken together, these results suggest that reduced cellular SDC1 or increased stromal SDC1 expression can be useful prognostic factors 
in oral cancers. However, a full understanding of the contrasting characteristics between epithelial and stromal components requires further studies.

\section{Ovarian cancer}

Patients with advanced ovarian cancer exhibit significantly lower epithelial SDC1 expression and significantly higher stromal SDC1 expression in reciprocal pattern compared to normal controls [103]. Additional studies have evaluated the expression of syndecans in benign and malignant ovarian tumors and found that SDC2, -3 , and -4 are expressed in normal, benign, and malignant ovarian tissues [104]. In contrast, SDC1 was absent in normal ovarian tissues, but present in epithelial and stromal cells of benign and borderline tumors. In addition, the expression of stromal SDC1 was a poor prognostic factor of overall survival in patients with ovarian cancer [104].

\section{Pancreatic cancer}

Epithelial SDC1 has been observed in most human pancreatic carcinoma samples evaluated to date, and expression is predictive of a more favorable prognosis in patients undergoing curative surgery. In addition, stromal SDC1 expression was weak or negative in over $60 \%$ of the tumors evaluated, and lack of stromal expression predicted a better prognosis in these patients [105].

\section{Prostate cancer}

Early studies have shown that syndecans are expressed in the epithelial cells of prostate cancer patients [106]. SDC1 showed basolateral membrane localization, whereas SDC2 was preferentially expressed in basal cells. Another study found that the expression patterns of SDC1 and SDC2 changed to a granular-cytoplasmic localization in prostate cancer samples [106]. Moreover, SDC1 was detected by immunostaining of a tissue microarray in approximately one third of patients with localized prostatic adenocarcinoma who had been treated with radical prostatectomy and bilateral lymphadenectomy [107]. SDC1 expression was also associated with lymph node metastases and aggressive progression after surgery. Further studies showed altered expression of SDC1 protein in specimens obtained from normal, benign, and malignant prostate tissues [108]. SDC1 overexpression in human prostate cancer was also predictive of early recurrence and was associated with tumor-specific survival, high Gleason grade, the Ki-67 mitosis marker, and $\mathrm{Bcl}-2$ overexpression [109]. Together, these findings suggest that expression of SDC1 can be used as a prognostic marker for patients with localized and advanced prostate cancer.
Squamous cell carcinoma of the head and neck and thyroid cancer

Analysis of primary squamous cell carcinoma of the head and neck in patients treated with surgery and post-operative radiotherapy has shown low SDC1 expression [110], which was associated with low grade of differentiation, large tumor size, increased nodal metastases, high clinical stage, and unfavorable overall survival [110]. SDC1 expression in these tumors was also associated with higher overall and recurrence-free survival compared to no or low SDC1 expression [111]. A tissue microarray analysis of SDC1 expression in papillary carcinomas of the thyroid indicated that SDC1 was mainly expressed in the cytoplasm of epithelial cells and stroma of papillary carcinomas of the thyroid [113].

\section{SDC1 as a prognostic biomarker in hematological tumors}

\section{Chronic lymphocytic leukemia}

Studies assessing the correlation between soluble SDC1 in plasma and clinical outcome in patients with chronic lymphocytic leukemia have shown that soluble SDC1 levels were significantly higher in these patients compared to healthy control subjects. In addition, high levels of soluble SDC1 were also associated with shorter overall survival [112].

\section{Diffuse large B-Cell lymphoma}

Multiple studies have detected SDC1 in diffuse large B-cell lymphoma [113, 114]. Tumor biopsies of diffuse large B-cell lymphoma patients were examined for SDC1 expression and results tested positive in $30 \%$ of poor overall survival $[113,114]$, indicating aberrant SDC1 expression correlates with poor clinical outcome.

\section{Multiple myeloma}

Several studies have shown higher levels of soluble SDC1 in multiple myeloma patients compared to healthy controls [115-117]. Baseline levels of soluble SDC1 at the time of diagnosis in patients who responded to chemotherapy were lower than non-responders; however, baseline levels of SDC1 did not predict therapeutic response in those patients [115]. High levels of soluble SDC1 and lower expression of cellular SDC1 at the time of diagnosis are negative prognostic factors for multiple myeloma [116]. In a cohort of Korean patients diagnosed with multiple myeloma, soluble SDC1 levels correlated with disease stage and characteristics [118]. In addition, high soluble SDC1 levels detected in Korean subjects were associated with poor survival [118]. Further studies showed that soluble SDC1 levels were elevated in the sera of multiple myeloma patients treated with high-dose chemotherapy and subsequent autologous transplantation [119]. In another study, the extent to which soluble 
SDC1 levels fell from presentation to the plateau phase represented a prognostic predictor in multiple myeloma patients [56]. In a comparative study of blood dyscrasias, multiple myeloma patients showed higher serum SDC1 levels than patients with plasmocytoma or monoclonal gammopathy [120]. In addition, serum SDC1 levels were diminished in patients who responded well to chemotherapy, whereas no change was observed in nonresponders [120]. When SDC1 expression was analyzed in normal bone marrow or bone marrow from multiple myeloma and B-cell lymphoma patients, SDC1 was found to be expressed predominantly in normal and neoplastic plasma cells. Moreover, high SDC1 expression was detected in all multiple myeloma cases examined, whereas all B-cell lymphomas were completely negative.

Evaluation of SDC1 levels in the bone marrow of multiple myeloma patients showed much higher levels than circulating SDC1 levels in peripheral blood [121]. Nevertheless, SDC1 blood and bone marrow levels were positively correlated with microvessel density, HGF levels, and reduced survival [121]. Serum SDC1 and bFGF/FGF2 levels were elevated in multiple myeloma patients before treatment compared to the control group [122]. Baseline assessment of SDC1 and bFGF/FGF2 serum levels showed higher levels of both markers, which was associated with shorter survival than patients with normal levels [122]. In the same study, myeloma patients responding to chemotherapy treatment showed reduced SDC1 levels [122]. Bone marrow levels of soluble SDC1 and HGF were elevated in multiple myeloma patients compared to control subjects [117]. In addition, HGF existed in a complex form with soluble SDC1 in pleural effusions, suggesting an important role of soluble SDC1 as a carrier for HGF in the pathology of myeloma [117]. Taken together, various studies have demonstrated SDC1 as a potential biomarker for multiple myeloma. Findings from these studies indicate that soluble SDC1 levels may be a prognostic tool in multiple myeloma patients for diagnosis, prognosis, and treatment response.

\section{Putative roles of SDC1 in Hodgkin's lymphoma}

Hodgkin's Lymphoma (HL) is characterized by the presence of cancerous Hodgkin-Reed-Sternberg (HRS) cells embedded in a background of immune, inflammatory and stromal cells [123]. These cells secrete a plethora of cytokines and growth factors in the tumor microenvironment that lead to tumor growth and dissemination. SDC1 acts to potentiate the signaling of cancerous and stromal cells in the tumor microenvironment. Serum levels of SDC1 were higher in HL specimens compared to a control group [124]. In another study, B-cell markers, including SDC1, were expressed in $38 \%$ of classical HL cases [125]. The following sections highlight three potential pathways involving $\mathrm{SDC} 1$ in $\mathrm{HL}$ pathogenesis.

\section{SDC1 and HGF}

It has been reported that HL patients have increased serum levels of HGF, which correlates with advanced stages of the disease [126]. SDC1 binds to HGF, which potentiates c-Met downstream signaling by activating the PI3K and ERK pathways (Figure 2) [127]. Moreover, it has been reported that c-Met is expressed by subsets of Hodgkin Reed Sternberg (HRS) cells, and HGF is secreted in the tumor milieu, suggesting an autocrine effect in $\mathrm{HL}$ pathogenesis [128]. In another study, changes in plasma heparanase levels correlated with the response to treatment in pediatric patients diagnosed with HL [57]. Heparanase induced HGF expression and shedding of SDC1 through the upregulation of matrix metaloprotease-9 (MMP-9) and urokinase-type plasminogen activator (UPA) [129]. These findings suggest that SDC1 or soluble SDC1 binds to HGF to facilitate binding and activation of its receptor (Figure 2).

\section{SDC1 and VEGF}

Angiogenesis is a crucial process during the progression of hematological malignancies, including $\mathrm{HL}$ [126]. High serum levels of VEGF were detected in the sera of HL patients [126]. Moreover, the levels of VEGF and VEGF receptor in HL patients were significantly higher than the levels in non-Hodgkin's lymphoma (NHL) patients [130]. In another study, the overexpression of VEGF was approximately $70 \%$ of cases of classical HL and $30 \%$ of nodular lymphocyte predominance $\mathrm{HL}$, and all neoplastic HRS cells [131]. In a separate study, VEGF-A, VEGF receptor-1, and VEGF receptor-2 were expressed in HRS cells from patients with classical HL [132]. When heparanase expression was high in the tumor, soluble SDC1 formed a complex with VEGF, which activated VEGF receptors on adjacent endothelial cells (Figure 2) [30]. These findings suggest that SDC1 or soluble SDC1 enhance VEGF binding to the VEGF receptor, thus promoting angiogenesis (Figure 2).

\section{SDC1 and bFGF/FGF2}

Unlike other growth factors, FGFs act with HSPGs (such as SDC1) to activate FGF receptors and induce downstream signaling responses [133, 134]. As described above, the binding of $\mathrm{bFGF} / \mathrm{FGF} 2$ and an HSPG to the extracellular domain of the FGF receptor induces receptor autophosphorylation. This process leads to the phosphorylation of docking molecules, such as Shc, phospholipase-C $\gamma$, STAT1, Gab1, and FRS2 $\alpha$, which are regulators of the Ras/MAPK and PI-3K/Akt signaling pathways (Figure 2) [133]. It has been reported that serum levels of bFGF were elevated and correlated with the stage of different hematological malignancies [135]. In addition, the event-free survival rate was higher in NHL patients who had lower bFGF levels [136]. Another study showed that high serum levels of bFGF are associated with a poor outcome in NHL patients [137]. It has been 
reported that HRS cells and stromal cells secrete bFGF, which stimulates fibrosis in the nodular sclerosis (NS) subtype of HL [123]. In addition, serum bFGF levels were significantly higher in HL patients than in healthy individuals and correlated with the clinical outcome of HL [126]. Expression levels of FGFs and their receptors were high in HL patient samples, while their expression in HL cell line cultures was stimulated in response to paracrine factors [133]. The expression of bFGF and SDC1 in HL suggests that they play a role in maintaining the growth of HL cells [138]. The association of high serum levels of both SDC1 and bFGF with poor outcome in lung cancer has been reported [93]. Furthermore, Kyrtsonis and colleagues demonstrated that patients who had high serum levels of both SDC1 and bFGF had a shorter overall survival than patients with normal levels, and responders to treatment regimens showed reduced SDC1 levels [122]. In addition, a bioinformatics analysis showed overexpression of bFGF and SDC1 in HL cell lines that were originally derived from primary HRS cells isolated from extranodal sites of refractory or relapsing HL patients [138]. The expression levels of bFGF and SDC1 protein were significantly elevated in HL patient samples compared to NHL sections and normal lymph node controls [138]. Furthermore, all HL tissue samples overexpressed $F G F 2$ and $S D C 1$ genes, and the group with a poor outcome had a 24-fold higher expression of $F G F 2$ and 56-fold higher expression of SDC1 than the group with a favorable outcome. Strong immunostaining of bFGF and SDC1 was also reported in the poor outcome HL group [138]. Taken together, these findings suggest that simultaneous high levels of bFGF and SDC1 correlate with a poor prognosis in HL patients.

\section{Syndecan as a therapeutic target in clinical settings}

Based on the numerous roles in cancer pathology, SDC1 is an attractive molecular target for therapeutic strategies. Quantification of SDC1 is necessary in basic discovery research as well as in clinical practice. In vitro diagnostics and technologies that allow for the specific detection and precise quantification of SDC1 continue to evolve. Today, selected clones that produce monoclonal antibodies can be cultured to produce SDC1-specific antibodies. This part of the review sheds light on recent advances in in vitro diagnostics as well as research-use only diagnostics (Table 4). It also summarizes SDCtargeting therapeutic modalities (Figure 3; Table 5) and the progress in clinical trials related to the SDC pathway (Table 6).

Synstatin is a short peptide that mimics the sequence of the SDC1 extracellular domain [139, 140]. This peptide antagonizes the SDC1 extracellular domain, which is responsible for capturing and activating $\alpha v \beta 3$

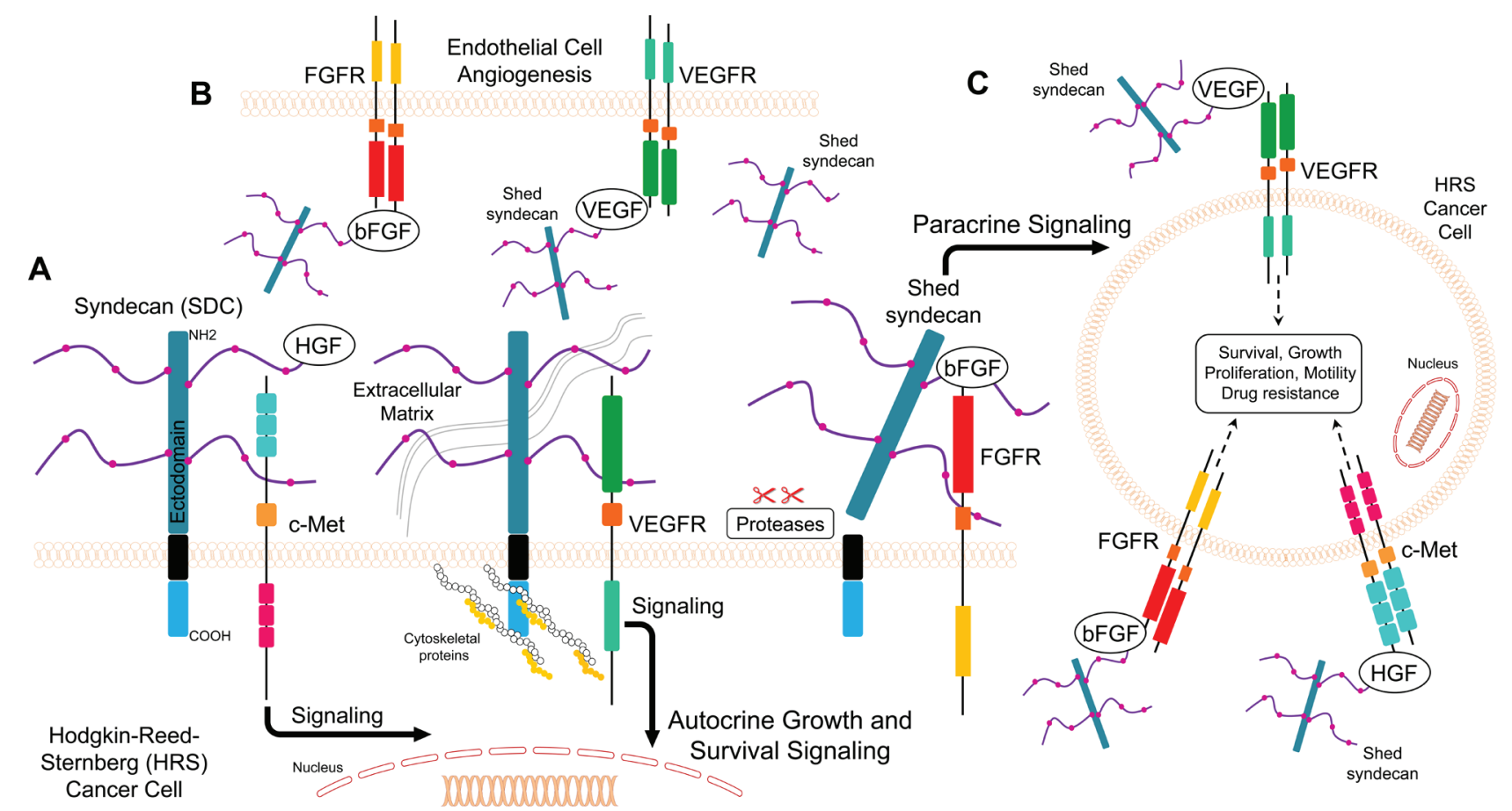

Figure 2: Model for putative roles of SDC1 in Hodgkin's lymphoma. A. SDC1 facilitates autocrine interaction between growth factors and their cognate receptors and enhances mitogenic signaling in Hodgkin-Reed-Sternberg (HRS) cancer cells B. Shed SDC1 (sSDC1) binds to growth factor VEGF and bFGF complexes with VEGFR and FGFRs in endothelial cells and promotes angiogenesis $\mathbf{C}$. Shed SDC1 (sSDC1) binds to growth factors to interact with cognate receptors on another HRS cell (paracrine effect). 
Table 4: In vitro diagnostics (IVD) and research use only (RUO) detection methods for SDC1.

\begin{tabular}{|c|c|c|c|c|c|c|c|}
\hline Diagnostic Type & $\begin{array}{l}\text { Source } \\
\text { (Host) }\end{array}$ & Reactivity & Manufacturer & Market Status & Applications & Cancer Type & Ref \\
\hline $\begin{array}{l}\text { Antibody } \\
\text { (Clone B-A38) }\end{array}$ & Mouse & $\begin{array}{l}\text { Amino acid sequence }(18-218) \\
\text { of human SDC1 }\end{array}$ & $\begin{array}{l}\text { Zeta Corporation (CA, USA) } \\
\text { Cell Marque (CA, USA) } \\
\text { Biocare Medical (CA, USA) }\end{array}$ & Class I IVD & $\begin{array}{l}\text { IHC } \\
\text { Flow cytometry }\end{array}$ & $\begin{array}{l}\text { Plasma cell } \\
\text { malignancies }\end{array}$ & [170] \\
\hline $\begin{array}{l}\text { Antibody } \\
\text { (Clone MI15) }\end{array}$ & Mouse & Ectodomain of human SDC1 & $\begin{array}{l}\text { Dako (CA, USA) } \\
\text { Genemed Biotechnologies (CA, USA) }\end{array}$ & Class I IVD & $\begin{array}{l}\text { IHC } \\
\text { Flow cytometry }\end{array}$ & $\begin{array}{l}\text { Plasma cell } \\
\text { malignancies }\end{array}$ & {$[170,171]$} \\
\hline $\begin{array}{l}\text { Antibody } \\
\text { (Clone ZMD.289) }\end{array}$ & Rabbit & $\begin{array}{l}\text { Middle region of human SDC1 } \\
\text { ectodomain }\end{array}$ & Thermo Fisher Scientific (MA, USA) & Class I IVD & IHC & $\begin{array}{l}\text { Plasma cell } \\
\text { malignancies }\end{array}$ & [172] \\
\hline $\begin{array}{l}\text { Antibody } \\
\text { (Clone EP201) }\end{array}$ & Rabbit & Ectodomain of human SDC1 & Diagnostic Biosystems (CA, USA) & Class I IVD & IHC & $\begin{array}{l}\text { Plasma cell } \\
\text { malignancies }\end{array}$ & * \\
\hline $\begin{array}{l}\text { Antibody } \\
\text { (Clone B-B4) }\end{array}$ & Mouse & $\begin{array}{l}\text { Amino acid sequence } \\
(90-93) \text { of human SDC1 }\end{array}$ & Miltenyi Biotech (Germany) & RUO & $\begin{array}{l}\text { IHC } \\
\text { Flow cytometry }\end{array}$ & $\mathrm{N} / \mathrm{A}$ & {$[170,173]$} \\
\hline $\begin{array}{l}\text { Antibody } \\
\text { (Clone DL-101) }\end{array}$ & Mouse & Ectodomain of human SDC1 & $\begin{array}{l}\text { Biolegend (CA, USA) } \\
\text { Affymetrix eBioscience (CA, USA) } \\
\text { Thermo Fisher Scientific (MA, USA) }\end{array}$ & RUO & $\begin{array}{l}\text { IHC } \\
\text { Flow cytometry }\end{array}$ & $\mathrm{N} / \mathrm{A}$ & {$[170]$} \\
\hline $\begin{array}{l}\text { Antibody } \\
\text { (Clone CLB-1D4) }\end{array}$ & Mouse & Ectodomain of human SDC1 & $\begin{array}{l}\text { Life Technologies (CT, USA) } \\
\text { Lifespan Biosciences (WA, USA) }\end{array}$ & RUO & $\begin{array}{l}\text { IHC } \\
\text { Flow cytometry }\end{array}$ & $\mathrm{N} / \mathrm{A}$ & {$[170,174]$} \\
\hline $\begin{array}{l}\text { Antibody } \\
\text { (Clone SP152) }\end{array}$ & Rabbit & Recombinant human SDC1 & $\begin{array}{l}\text { Pierce Antibodies (MA, USA) } \\
\text { Abcam (UK) } \\
\text { Lifespan Biosciences (WA, USA) }\end{array}$ & RUO & $\mathrm{IHC}$ & $\mathrm{N} / \mathrm{A}$ & $*$ \\
\hline Sandwich ELISA & Mouse & $\begin{array}{l}\text { Natural and recombinant soluble } \\
\text { human SDC1 }\end{array}$ & $\begin{array}{l}\text { Abnova (Taiwan) } \\
\text { BioVendor R\&D (Czech Republic) }\end{array}$ & RUO & ELISA & $\mathrm{N} / \mathrm{A}$ & {$[58]$} \\
\hline
\end{tabular}

IVD: in vitro diagnostic; RUO: research use only; *: information taken by contact with company.

Table 5: Agents targeting SDC1 in cancer.

\begin{tabular}{|c|c|c|c|c|c|c|c|}
\hline Target & Agent & Manufacturer & Agent Type & Characteristics & Status (Trial \#) & Indication & Ref \\
\hline \multirow[t]{5}{*}{$\begin{array}{l}\text { Extracellular } \\
\text { domain of SDC }\end{array}$} & Synstatin & - & Peptide & $\begin{array}{l}\text { Competes with SDC1 for binding to } \\
\text { EGFR/a.6B4 integrin complex }\end{array}$ & - & $\begin{array}{l}\text { Breast cancer, } \\
\text { multiple myeloma }\end{array}$ & {$[140]$} \\
\hline & $\begin{array}{l}\text { BT-062-DM4 } \\
\text { (Indatuximab } \\
\text { Ravtansine) }\end{array}$ & $\begin{array}{l}\text { Biotest } \\
\text { Pharmaceuticals } \\
\text { Corporation (FL, } \\
\text { USA) }\end{array}$ & $\begin{array}{l}\text { Antibody conjugated to a } \\
\text { cytotoxic agent (DM4) }\end{array}$ & $\begin{array}{l}\text { Selectively causes } \\
\text { SDC1+ cancer cell death }\end{array}$ & $\begin{array}{l}\text { Phase I/II (NCT01638936) } \\
\text { All patients achieved stable } \\
\text { disease }\end{array}$ & $\begin{array}{l}\text { Breast cancer, } \\
\text { bladder cancer, } \\
\text { multiple myeloma }\end{array}$ & {$[142]$} \\
\hline & $\begin{array}{l}\text { B-B4 conjugated to } \\
\mathrm{I}^{131}\end{array}$ & $\begin{array}{l}\text { Centre René } \\
\text { Gauducheau (France) }\end{array}$ & $\begin{array}{l}\text { Antibody conjugated to } \\
I^{131}\end{array}$ & $\begin{array}{l}\text { Selectively kills } \\
\text { SDC1+ cancer cell }\end{array}$ & $\begin{array}{l}\text { Phase I (NCT01296204) } \\
1 / 1 / \text { of patients exhibited partial } \\
\text { response }\end{array}$ & Multiple myeloma & {$[143]$} \\
\hline & OC-46F2 & - & Antibody & Reduces SDC1/VEGFR-2 interaction & - & $\begin{array}{l}\text { Melanoma, } \\
\text { ovarian cancer }\end{array}$ & {$[144]$} \\
\hline & GLVGLIFAV & - & Cytotoxic T lymphocytes & Selectively target SDC1+ cells & - & Multiple myeloma & {$[145]$} \\
\hline \multirow[t]{7}{*}{ Shed SDC } & NSC 405020 & - & Protein & $\begin{array}{l}\text { Inhibits MT1-MMP } \\
\text { homodimerization }\end{array}$ & - & Breast cancer & {$[146]$} \\
\hline & BB-94 & - & Small molecule & MMP inhibitor & $\begin{array}{l}\text { Phase III } \\
\text { (discontinued) }\end{array}$ & Breast cancer & [147] \\
\hline & $\mathrm{PI}-88$ & \multirow[t]{3}{*}{$\begin{array}{l}\text { Progen } \\
\text { Pharmaceuticals } \\
\text { (Australia) }\end{array}$} & Small molecule & Heparanase inhibitor & $\begin{array}{l}\text { Phase III (NCT01402908) } \\
\text { (ongoing) }\end{array}$ & Liver cancer & {$[150]$} \\
\hline & PG545 & & Small molecule & Heparanase Inhibitor & Phase I NCT02042781 (ongoing) & Solid tumors & {$[175]$} \\
\hline & M402 & & Small molecule & Heparanase Inhibitor & $\begin{array}{l}\begin{array}{l}\text { Phase I/II NTC01621243 } \\
\text { (ongoing) }\end{array} \\
\end{array}$ & Pancreatic cancer & {$[176]$} \\
\hline & SST00001 & - & Modified heparin & Heparanase Inhibitor & $\begin{array}{l}\text { Phase I (NCT01764880) } \\
\text { (ongoing) }\end{array}$ & Multiple myeloma & {$[177]$} \\
\hline & Pentraxin-3 & - & Protein & FGF2 antagonist & - & Pancreatic cancer & {$[157]$} \\
\hline \multirow{4}{*}{$\begin{array}{l}\text { Genetic expression } \\
\text { of SDC }\end{array}$} & All-trans retinoic acid & - & Micronutrient & Inhibits $\mathrm{B} \alpha \mathrm{P}$-induced shedding & - & Lung cancer & {$[155]$} \\
\hline & Nimesulide & - & Small molecule & $\begin{array}{l}\text { Downregulates SDC1, SDC2 } \\
\text { expression }\end{array}$ & - & $\begin{array}{l}\text { Primary effusion } \\
\text { lymphoma }\end{array}$ & {$[159]$} \\
\hline & $\begin{array}{l}\text { Zoledronic acid } \\
\text { (Zometa) }\end{array}$ & \multirow[t]{2}{*}{$\begin{array}{l}\text { Novartis } \\
\text { (Switzerland) }\end{array}$} & Small molecule & $\begin{array}{l}\text { Downregulates SDC1, SDC2 } \\
\text { expression }\end{array}$ & - & Breast cancer & {$[161]$} \\
\hline & Imatinib (Glivec) & & Small molecule & $\begin{array}{l}\text { Downregulates SDC2, SDC4 } \\
\text { expression }\end{array}$ & - & Breast cancer & {$[162]$} \\
\hline
\end{tabular}

SDC: Syndecan; EGFR: epidermal growth factor receptor; VEGFR: vascular endothelial growth factor receptor; MT1-MMP: membrane type 1 metalloprotease; FGF2: fibroblast growth factor-2.

or $\alpha v \beta 5$ integrins and the insulin-like growth factor-I (IGF-I) receptor (Figure 3). Synstatin competitively displaces the integrin and IGF-I receptor kinase from SDC1 and inactivates the complex, which makes it a promising anti-angiogenic agent [139, 140]. BT062 (Indatuximab Ravtansine) is an antibody-drug conjugate that is comprised of the anti-SDC1 chimerized monoclonal antibody and the cytotoxic agent DM4. Once bound to SDC1 on the cell, the conjugate is internalized and releases DM4, which consequently leads to cell death.
A study was conducted to evaluate the effect of BT062 on multiple myeloma patients heavily pretreated with revelimid, thalidomide, velcade, or carlfilzomid [141, 142]. BT062 was well-tolerated in patients and 4\% achieved partial response, $8 \%$ had a minor response, while $38 \%$ showed stable disease [141]. B-B4 is a monoclonal IgG1 antibody conjugated to cytotoxic drugs or radioactive isotopes. A phase I/II radioimmunotherapy study using B-B4 conjugated to iodine-131 was conducted in refractory multiple myeloma patients [143] and 
Table 6: Clinical trials related to the SDC1 pathway.

\begin{tabular}{|c|c|c|c|c|c|c|c|}
\hline $\begin{array}{l}\text { Clinical Trial Description } \\
(\text { Trial \#) }\end{array}$ & $\begin{array}{l}\text { Participants } \\
\#\end{array}$ & $\begin{array}{l}\text { Start Date/ } \\
\text { Trial Status }\end{array}$ & Originator & Sponsor & $\begin{array}{l}\text { Agent Type / Mechanism of } \\
\text { Action }\end{array}$ & Study Type/ Purpose & Ref \\
\hline $\begin{array}{l}\text { Phase I/II multi-dose escalation study of BT062 (Indatixumab } \\
\text { Ravtansine) in combination with lenalidomide and dexamethasone } \\
\text { in subjects with relapsed multiple myeloma } \\
\text { (NCT01638936) }\end{array}$ & 49 & $\begin{array}{l}\text { July 2012/ } \\
\text { recruiting - } \\
\text { ongoing }\end{array}$ & \multicolumn{2}{|c|}{$\begin{array}{l}\text { Biotest Pharmaceutical Co. (FL, } \\
\text { USA) }\end{array}$} & $\begin{array}{l}\text { Monoclonal SDC1 antibody } \\
\text { coupled with cytotoxic agent } \\
\text { (DM4)/ inhibits tubulin } \\
\text { polymerization }\end{array}$ & $\begin{array}{l}\text { Interventional, optimal dosage } \\
\text { determination, evaluation of } \\
\text { response, dose escalation study }\end{array}$ & {$[142]$} \\
\hline $\begin{array}{l}\text { Phase I open-label, dose-finding study evaluating safety and } \\
\text { pharmacokinetics of FPA144 in patients with advanced solid } \\
\text { tumors } \\
\text { (NCT02318329) }\end{array}$ & 100 & $\begin{array}{l}\text { November } \\
2014 / \\
\text { recruiting - } \\
\text { ongoing }\end{array}$ & \multicolumn{2}{|c|}{$\begin{array}{l}\text { Five Prime Therapeutics, Inc. (CA, } \\
\text { USA) }\end{array}$} & $\begin{array}{l}\text { Monoclonal FGFR2 antibody/ } \\
\text { FGFR2 antagonist }\end{array}$ & $\begin{array}{l}\text { Interventional, safety of escalating } \\
\text { doses }\end{array}$ & {$[178]$} \\
\hline $\begin{array}{l}\text { Phase III, pivotal study of SGN-35 (Adcetris } \mathbb{R} \text {; Brentiximab } \\
\text { Vedotin) in treatment of patients with relapsed or refractory } \\
\text { Hodgkin lymphoma } \\
\text { (NCT00848926) }\end{array}$ & 102 & $\begin{array}{l}\text { February } \\
2009 / \text { active, } \\
\text { not recruiting } \\
\text { - ongoing }\end{array}$ & \multicolumn{2}{|c|}{ Seattle Genetics (WA, USA) } & $\begin{array}{l}\text { Immunoconjugate } \\
\text { monoclonal antibody against } \\
\text { integrin } \alpha v \beta 3 / \text { tubulin } \\
\text { polymerization inhibitor }\end{array}$ & $\begin{array}{l}\text { Interventional, best clinical } \\
\text { outcome, } 75 \% \text { of participants } \\
\text { responded to treatment }\end{array}$ & [179] \\
\hline $\begin{array}{l}\text { Phase I study assessing safety and tolerability of SST0001 } \\
\text { (Roneparstat) in advanced multiple myeloma } \\
\text { (NCT01764880) }\end{array}$ & 30 & $\begin{array}{l}\text { November } \\
2012 / \\
\text { recruiting - } \\
\text { ongoing }\end{array}$ & \multicolumn{2}{|c|}{$\begin{array}{l}\text { Sigma Tau Research Switzerland } \\
\text { SA (Italy) }\end{array}$} & $\begin{array}{l}\text { Chemically-modified heparin/ } \\
\text { heparanase inhibitor }\end{array}$ & $\begin{array}{l}\text { Interventional, maximum } \\
\text { tolerated dose with primary } \\
\text { purpose of treatment }\end{array}$ & * \\
\hline $\begin{array}{l}\text { Phase I study evaluating the toxicity, pharmacokinetics and } \\
\text { biological effect of intravenous Bevacizumab (Avastin }{ }^{\mathrm{TM}} \text { ) in } \\
\text { combination with escalating doses of oral AZD2171 (Recentin } \\
\text { Cediranib) for patients with advanced malignancies } \\
\text { (NCT00458731) }\end{array}$ & 57 & $\begin{array}{l}\text { May } 2007 / \\
\text { completed }\end{array}$ & $\begin{array}{l}\text { Bevacizumab: } \\
\text { Genentech ( } \\
\text { CA, USA); } \\
\text { Recentin: } \\
\text { AstraZeneca } \\
\text { (DE, USA) }\end{array}$ & $\begin{array}{l}\text { National Cancer } \\
\text { Institute (MD, } \\
\text { USA) }\end{array}$ & $\begin{array}{l}\text { Bevacizumab: VEFG-A } \\
\text { monoclonal antibody/ } \\
\text { VEGFR signaling inhibitor } \\
\text { Recentin: quinazoline small } \\
\text { molecule / VEGFR antagonist }\end{array}$ & $\begin{array}{l}\text { Interventional, safety study with } \\
\text { primary purpose of treatment }\end{array}$ & {$[180]$} \\
\hline $\begin{array}{l}\text { Phase I dose escalation study of OMP-54F28 (Ipafricept) in subjects } \\
\text { with solid tumors } \\
\text { (NCT01608867) }\end{array}$ & 36 & $\begin{array}{l}\text { June 2012/ } \\
\text { active, not } \\
\text { recruiting - } \\
\text { ongoing }\end{array}$ & $\begin{array}{l}\text { OncoMed } \\
\text { Pharmaceutical } \\
\text { s, Inc. (CA } \\
\text { USA) }\end{array}$ & $\begin{array}{l}\text { Bayer } \\
\text { Healthcare } \\
\text { Pharma. } \\
\text { (Germany) }\end{array}$ & $\begin{array}{l}\text { Immunoglobulin fusion } \\
\text { proteins/ Wnt pathway } \\
\text { inhibitor, targets R-spondin }\end{array}$ & 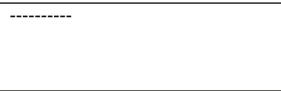 & {$[181]$} \\
\hline $\begin{array}{l}\text { Phase II study of VS-6063 (Defactnib) in patients with KRAS } \\
\text { mutant non-small cell lung cancer } \\
\text { (NCT01951690) }\end{array}$ & 150 & $\begin{array}{l}\text { September } \\
2013 / \\
\text { recruiting - } \\
\text { ongoing }\end{array}$ & \multicolumn{2}{|c|}{$\begin{array}{l}\text { Pfizer (New York, NY USA)// } \\
\text { Verstern, Inc. (MA USA) }\end{array}$} & $\begin{array}{l}\text { Small molecule/FAK } \\
\text { Inhibitor }\end{array}$ & $\begin{array}{l}\text { Interventional, PFS improvement } \\
\text { was measured every } 12 \text { weeks }\end{array}$ & {$[182]$} \\
\hline $\begin{array}{l}\text { Phase I open-label dose escalation study of GSK2256098 in } \\
\text { subjects with solid tumors } \\
\text { (NCT01138033) }\end{array}$ & 138 & $\begin{array}{l}\text { July } 2010 / \\
\text { recruiting - } \\
\text { ongoing }\end{array}$ & \multicolumn{2}{|c|}{ GlaxoSmithKline (NJ, USA) } & $\begin{array}{l}\text { Small molecule/ FAK } \\
\text { Inhibitor }\end{array}$ & $\begin{array}{l}\text { Interventional, safety and } \\
\text { tolerability with primary purpose } \\
\text { of treatment }\end{array}$ & [183] \\
\hline $\begin{array}{l}\text { Phase I/II study to evaluate the safety and efficacy of M402 } \\
\text { (Necuparanib) in combination with nab-paclitaxel and gemcitabine } \\
\text { in patients with metastatic pancreatic cancer (NCT01621243) }\end{array}$ & 180 & $\begin{array}{l}\text { May 2012/ } \\
\text { recruiting - } \\
\text { ongoing }\end{array}$ & \multicolumn{2}{|c|}{$\begin{array}{l}\text { Momenta Pharmaceuticals } \\
\text { (MA, USA) }\end{array}$} & $\begin{array}{l}\text { Necuparanib: } \\
\text { glysoaminoglycan / } \\
\text { heparanase Inhibitor }\end{array}$ & $\begin{array}{l}\text { Interventional, safety and overall } \\
\text { survival measured in response to } \\
\text { treatment }\end{array}$ & {$[153]$} \\
\hline $\begin{array}{l}\text { Phase I/II Study of PI-88 (Muparfostat) in malignancies (Phase I), } \\
\text { and in Advanced Melanoma (Phase II) } \\
\text { (NCT00068172) }\end{array}$ & 88 & $\begin{array}{l}\text { March 2009/ } \\
\text { completed }\end{array}$ & \multicolumn{2}{|c|}{ Progen Pharmaceuticals (Australia) } & $\begin{array}{l}\text { Mannan, oligosaccharide / } \\
\text { FGF inhibitor; heparanase } \\
\text { inhibitor; VEGF inhibitor }\end{array}$ & $\begin{array}{l}\text { Interventional, progression-free } \\
\text { survival }\end{array}$ & [151] \\
\hline $\begin{array}{l}\text { Phase I, open-label study of the safety and tolerability of PG545 in } \\
\text { patients with advanced solid tumors } \\
\text { (NCT01252095) }\end{array}$ & 4 & $\begin{array}{l}\text { January } \\
2011 / \\
\text { Terminated }\end{array}$ & \multicolumn{2}{|c|}{ Progen Pharmaceuticals (Australia) } & $\begin{array}{l}\text { Chemically modified heparin } \\
\text { sulfate/ heparanse inhibitor }\end{array}$ & $\begin{array}{l}\text { Interventional, maximum } \\
\text { tolerated dose was measured }\end{array}$ & [152] \\
\hline $\begin{array}{l}\text { Phase I study of intrapleural batimastat (BB-94) in the treatment of } \\
\text { malignant pleural effusions }\end{array}$ & 18 & - & \multicolumn{2}{|c|}{ British Biotech (UK) } & $\begin{array}{l}\text { Amino acids/matrix } \\
\text { metalloprotease inhibitor }\end{array}$ & $\begin{array}{l}\text { Interventional; optimal dosage } \\
\text { determination }\end{array}$ & [149] \\
\hline $\begin{array}{l}\text { Study of Chimeric CD138 antigen receptor-modified T cells in } \\
\text { relapsed and/or refractory multiple myeloma patients } \\
\text { (NCT01886976) }\end{array}$ & 10 & $\begin{array}{l}\text { June } 2013- \\
\text { ongoing / } \\
\text { recruiting }\end{array}$ & \multicolumn{2}{|c|}{ Chinese PLA General Hospital } & $\begin{array}{l}\text { Chimeric anti-CDI38 antigen } \\
\text { receptor-modified T cells }\end{array}$ & $\begin{array}{l}\text { Interventional, safety and } \\
\text { tolerability with primary purpose } \\
\text { of treatment }\end{array}$ & {$[163]$} \\
\hline
\end{tabular}

*https://clinicaltrials.gov/ct2/show/NCT01764880

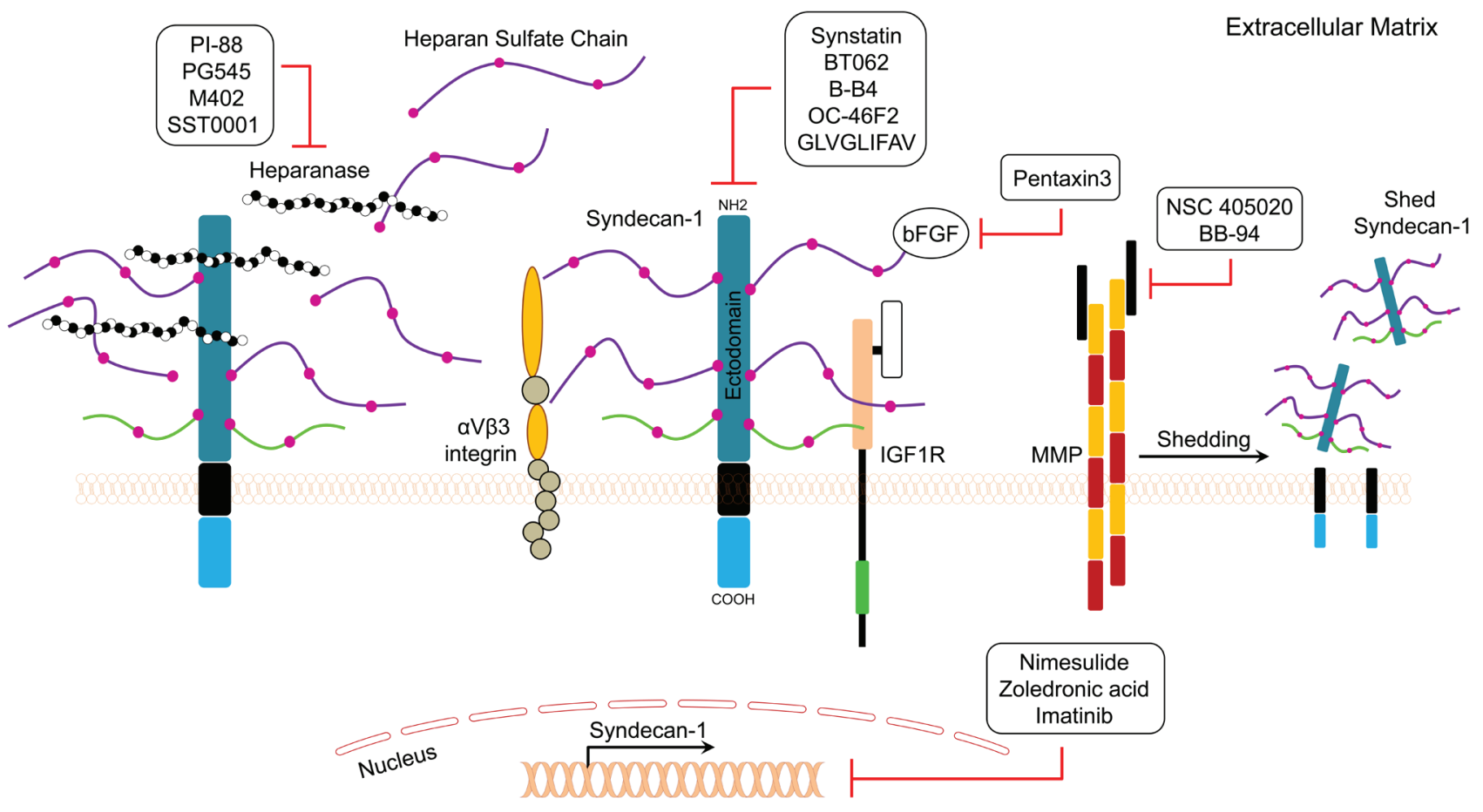

Figure 3: General mechanisms of action of SDC1 pathway inhibitors are depicted. 
significantly improved clinical outcome than the control group, suggesting that targeted radioimmunotherapy is feasible using an anti-SDC1 monoclonal antibody [143].

$\mathrm{OC}-46 \mathrm{~F} 2$ is a fully human recombinant that specifically recognizes the SDC1 ectodomain (Figure 3) [144]. OC-46F2 was found to inhibit SDC1 distribution in the tumor milieu, thus preventing vascular maturation and tumor growth in experimental human melanoma and ovarian carcinoma models [144]. GLVGLIFAV is an SDC1-specific peptide that is recognized by cytotoxic $\mathrm{T}$ lymphocytes generated ex vivo using an HLA-A2specific SDC1 epitope against multiple myeloma cells [145]. The GLVGLIFAV peptide induces antigen-specific cytotoxic T lymphocytes, which might be useful for the treatment of multiple myeloma patients with peptidebased vaccines or cellular immunotherapy strategies [145]. Membrane type 1 metalloprotease (MT1-MMP) is a transmembrane metalloprotease that stimulates the shedding of several proteoglycans, such as SDC1. NSC 405020 is a small molecule inhibitor that inhibits MT1-MMP homodimerization, thus blocking its protumorigenic activity in vivo [146]. BB-94 (Batimastat) is a potent, broad spectrum small molecule inhibitor of MMP [147]. Treatment of cells with BB-94 suppressed SDC1 shedding and induced accumulation of SDC1 on the cell surface [148]. On patients with cytologically positive malignant pleural effusions in Phase I study of intrapleural BB-94, BB-94 peaked after $4 \mathrm{~h}$, and remained in plasma for up to 12 weeks, indicating that the intrapleural BB-94 was well tolerated, with evidence of local efficacy [149].

PI-88 is a polysaccharide compound with antiheparanase activity (Figure 3) [52]. In a phase II study in hepatocellular carcinoma (HCC) patients, PI-88 treatment was administered over nine, 4-week treatment cycles, followed by a 12 -week treatment-free period. PI-88 at 160 $\mathrm{mg}$ /day was tolerable and effective as an adjunct therapy for post-surgery HCC [150]. In another phase I study in patients with advanced solid tumors, the compound was found to be well-tolerated when administered for 4 consecutive days bimonthly or weekly at the recommended dose of $250 \mathrm{mg} /$ day [151]. One melanoma patient had a partial response, and nine patients maintained a stable disease state for more than six months [151]. M402 is another modified heparin compound similar to SST0001, a chemically modified heparin to inhibit myeloma growth [152]. PG545 is a fully sulfated, synthetic tetrasaccharide that exerts anti-heparanase activity and has shown promising results against many cancer cells[152]. In ovarian cancer cells, PG545 showed synergistic inhibition of growth and migration in combination with paclitaxel and cisplatin [152]. M402 is smaller than SST0001 and has broader activity in binding to growth factors. M402 was found to be an effective anticancer agent in different cancer models [152]. M402 inhibits stromal activation and reduces tumor size in nude mice with human pancreatic cancer cells [153] . An ongoing Phase I/II study evaluating the safety and tolerability of M402 is currently being conducted in patients with metastatic pancreatic cancer [153]. SST0001 is a modified heparin with anti-heparanase activity that inhibits cancer cell growth and metastasis [154]. Results of in vivo studies showed that SST0001 effectively inhibited myeloma growth and diminished heparanase-induced shedding of SDC1 [154].

All-trans retinoic acid, an active metabolite of retinal, has been shown to exert anticancer activity against different cancer cells. It has been reported that benzo $(\alpha)$ pyrene induces accumulation of shed SDC1 in lung cancer [155]. One study examined the level of SDC1 expression and the chemopreventive effect of all-trans retinoic acid in a benzo $(\alpha)$ pyrene-induced lung cancer model in BALB/c mice. The results indicated that all-trans retinoic acid inhibited lung tumor development and reduced SDC1 expression in cancer cells [155]. It has been reported that bFGF/FGF2 induces shedding of SDC1 in cancer cells [156]. Pentraxin-3 is a bFGF antagonist that binds to bFGF with high affinity and prevents the binding of bFGF to its receptor [157]. Therefore, pentraxin-3 may be of value to inhibit SDC1 shedding induced by bFGF (Figure 3) [156].

Nimesulide is a cyclooxygenase-2 selective, non-steroidal anti-inflammatory drug [158]. Paul and colleagues reported that nimesulide treatment caused cell cycle arrest in primary effusion lymphoma cell lines, and this effect was accompanied by downregulation of SDC1 [159]. Zoledronic acid (Zometa ${ }^{\circledR}$ ) is a third-generation bisphosphonate that inhibits SDC1 expression in cancer cells in a dose-dependent manner [160]. Moreover, zoledronic acid effectively inhibited growth, migration, and adhesion of human breast cancer cells, which was accompanied by downregulation of SDC1 and -2 [161]. Moreover, imatinib $\left(\right.$ Gleevec $\left.^{\circledR}\right)$ is a tyrosine kinase inhibitor of PDGF receptor, c-Kit, and Bcr-Abl. It exerts a significant inhibitory effect on the expression of SDC2 and SDC4 in cancer cells, which leads to suppression of cell growth ability, migration, and invasion (Figure 3) [162]. More recently, a clinical trial was conducted to evaluate the safety and efficacy of autologous T cells expressing an anti-CD138 chimeric antigen receptor (CART138) in patients with relapsed or refractory multiple myeloma [163] and results showed that CART-138 immunotherapy was well-tolerated with significant clinical benefits in multiple myeloma patients [163].

\section{CONCLUSIONS}

SDC1 is a cell surface adhesion molecule that is essential for maintaining cell morphology and interactions with the microenvironment. SDC1 exerts specific functional roles by acting as a coreceptor, thus potentiating binding between growth factors and their membrane receptors. Proteolytic activity releases the extracellular ectodomain of SDC1, which harbors both the HS and $\mathrm{CS}$ chains, thus resulting in soluble/shed SDC1. Soluble 
SDC1 facilitates binding between growth factors and their receptors, or functions as a decoy receptor in other circumstances. SDC1 can be found in the cytoplasmic compartment as well as the nuclear compartment of cells. Nuclear SDC1 can activate gene transcription and result in distinct physiologic activities. In cancer, growing evidence indicates that deregulation of SDC1 contributes to the development and progression of different tumor types. The value of SDC1 as a prognostic marker for specific cancer types has been extensively evaluated in solid and hematological cancers. In addition, multiple reports have examined the prognostic impact of the cellular localization of SDC1. However, based on the data to date, it is difficult to directly correlate the levels of SDC1 expression with tumor characteristics and prognostic significance for all cancers in general and formulate personalized clinical treatment approaches. However, the concept of precision medicine can be implicated for specific cancer types, since higher or lower SDC1 expression is directly associated with more aggressive tumors and decreased patient survival in some cases. Such profiling may be useful for patient selection at the time of diagnosis or perhaps for relapsing patients. In addition, SDC1 expression is associated with a weaker response to chemotherapy for numerous solid tumors, including breast, colorectal, and prostate cancers. Therefore, appropriately targeting SDC1 in selected cancers may guide precision therapeutic options. The reciprocal expression signature of SDC1 whereby expression is reduced in tumor epithelium and increased in tumor stroma has been evaluated in multiple studies, and recent reports suggest that $\mathrm{SDC} 1$ plays a functional role in cancer-activated stromal components as well as in tumor progression in selected cancer types. Interestingly, most studies have shown distinct cellular expression patterns for SDC1, in which membranous and cytoplasmic expression profiles were different in tumor samples compared to control samples from different types of cancers. Therefore, it can be concluded that total expression levels as well as the cellular distribution of SDC1 should be evaluated together for the most informative prognostic tools. Evaluation of urinary levels of SDC1 in urinary bladder tumors may also be considered during the assessment of tumor severity. The value of circulating levels of SDC1 was not consistently associated with tumor grade or characteristics, but the combination of SDC1 and bFGF/FGF2 in patient serum has a strong association with tumor progression and prognosis in selected cancer types. In multiple myeloma, soluble SDC1 levels were found to be directly associated with the progression of disease, and therefore this association should be evaluated in other cancers as well. Multiple clinical trials are currently evaluating the safety and efficacy of pharmacologically targeting SDC1 in different types of cancer. Collectively, SDC1 represents an attractive molecular target for further evaluation in personalized cancer treatment. The identification and clinical validation of SDC1 as a new diagnostic and predictive biomarker will enable individualized therapeutic management for poor outcome cancer patients who are refractory to therapy or under high risk of relapse.

\section{ACKNOWLEDGMENTS}

We thank Lisa B. Fishman Foundation and the John Theurer Cancer Center and Hackensack University Medical Center for supporting funds and preparation of this manuscript.

\section{CONFLICTS OF INTEREST}

The authors declare no conflicts of interest.

\section{REFERENCES}

1. Tkachenko E, Rhodes JM and Simons M. Syndecans: new kids on the signaling block. Circ Res. 2005; 96:488-500.

2. Saunders S, Jalkanen M, O'Farrell S and Bernfield M. Molecular cloning of syndecan, an integral membrane proteoglycan. J Cell Biol. 1989; 108:1547-1556.

3. Marynen P, Zhang J, Cassiman J-J, Van den Berghe H and David G. Partial primary structure of the 48-and 90-kilodalton core proteins of cell surface-associated heparan sulfate proteoglycans of lung fibroblasts. Prediction of an integral membrane domain and evidence for multiple distinct core proteins at the cell surface of human lung fibroblasts. J Biol Chem. 1989; 264:7017-7024.

4. Carey DJ, Evans DM, Stahl RC, Asundi VK, Conner KJ, Garbes P and Cizmeci-Smith G. Molecular cloning and characterization of $\mathrm{N}$-syndecan, a novel transmembrane heparan sulfate proteoglycan. J Cell Biol. 1992; 117:191201.

5. David G, van der Schueren B, Marynen P, Cassiman J-J and Van den Berghe H. Molecular cloning of amphiglycan, a novel integral membrane heparan sulfate proteoglycan expressed by epithelial and fibroblastic cells. J Cell Biol. 1992; 118:961-969.

6. Bernfield M, Gotte M, Park PW, Reizes O, Fitzgerald ML, Lincecum J and Zako M. Functions of cell surface heparan sulfate proteoglycans. Annu Rev Biochem. 1999; 68:729777.

7. Granés F, Ureña JM, Rocamora N and Vilaró S. Ezrin links syndecan-2 to the cytoskeleton. J Cell Sci. 2000; 113:12671276.

8. Granés F, Berndt C, Roy C, Mangeat P, Reina M and Vilaró $\mathrm{S}$. Identification of a novel Ezrin-binding site in syndecan-2 cytoplasmic domain. FEBS letters. 2003; 547:212-216.

9. Sanderson RD, Lalor P and Bernfield M. B lymphocytes express and lose syndecan at specific stages of differentiation. Cell Regul. 1989; 1:27-35.

10. Couchman JR. Syndecans: proteoglycan regulators of 
cell-surface microdomains? Nat Rev Mol Cell Biol. 2003; 4:926-938.

11. Cizmeci-Smith G, Langan E, Youkey J, Showalter LJ and Carey DJ. Syndecan-4 is a primary-response gene induced by basic fibroblast growth factor and arterial injury in vascular smooth muscle cells. Arterioscler Thromb Vasc Biol. 1997; 17:172-180.

12. Halden Y, Rek A, Atzenhofer W, Szilak L, Wabnig A and Kungl AJ. Interleukin-8 binds to syndecan-2 on human endothelial cells. Biochem J. 2004; 377:533-538.

13. Dobra K, Nurminen $M$ and Hjerpe A. Growth factors regulate the expression profile of their syndecan coreceptors and the differentiation of mesothelioma cells. Anticancer Res. 2003; 23:2435-2444.

14. Gallo R, Kim C, Kokenyesi R, Adzick NS and Bernfield $\mathrm{M}$. Syndecans- 1 and -4 are induced during wound repair of neonatal but not fetal skin. J Invest Dermatol. 1996; 107:676-683.

15. Teng YH, Aquino RS and Park PW. Molecular functions of syndecan-1 in disease. Matrix Biol. 2012; 31:3-16.

16. Nugent MA and Edelman ER. Kinetics of basic fibroblast growth factor binding to its receptor and heparan sulfate proteoglycan: a mechanism for cooperativity. Biochemistry. 1992; 31:8876-8883.

17. Salmivirta M, Heino J and Jalkanen M. Basic fibroblast growth factor-syndecan complex at cell surface or immobilized to matrix promotes cell growth. J Biol Chem. 1992; 267:17606-17610.

18. Chu C, Buczek-Thomas J and Nugent M. Heparan sulphate proteoglycans modulate fibroblast growth factor-2 binding through a lipid raft-mediated mechanism. Biochem. J. 2004; 379:331-341.

19. Forsten-Williams K, Chua CC and Nugent MA. The kinetics of FGF-2 binding to heparan sulfate proteoglycans and MAP kinase signaling. J Theor Biol. 2005; 233:483499.

20. Koda JE, Rapraeger A and Bernfield M. Heparan sulfate proteoglycans from mouse mammary epithelial cells. Cell surface proteoglycan as a receptor for interstitial collagens. J Biol Chem. 1985; 260:8157-8162.

21. Salmivirta M, Elenius K, Vainio S, Hofer U, ChiquetEhrismann R, Thesleff I and Jalkanen M. Syndecan from embryonic tooth mesenchyme binds tenascin. J Biol Chem. 1991; 266:7733-7739.

22. Saunders S and Bernfield M. Cell surface proteoglycan binds mouse mammary epithelial cells to fibronectin and behaves as a receptor for interstitial matrix. J Cell Biol. 1988; 106:423-430.

23. Okamoto O, Bachy S, Odenthal U, Bernaud J, Rigal D, Lortat-Jacob H, Smyth N and Rousselle P. Normal human keratinocytes bind to the $\alpha 3 \mathrm{LG} 4 / 5$ domain of unprocessed laminin-5 through the receptor syndecan-1. J Biol Chem. 2003; 278:44168-44177.

24. Beauvais DM, Burbach BJ and Rapraeger AC. The syndecan-1 ectodomain regulates alphavbeta3 integrin activity in human mammary carcinoma cells. J Cell Biol. 2004; 167:171-181.

25. Choi Y, Chung H, Jung H, Couchman JR and Oh ES. Syndecans as cell surface receptors: Unique structure equates with functional diversity. Matrix Biol. 2011; 30:9399.

26. Bayer-Garner IB and Smoller BR. The expression of syndecan-1 is preferentially reduced compared with that of E-cadherin in acantholytic squamous cell carcinoma. J Cutan Pathol. 2001; 28:83-89.

27. Dhodapkar MV, Abe E, Theus A, Lacy M, Langford JK, Barlogie B and Sanderson RD. Syndecan-1 is a multifunctional regulator of myeloma pathobiology: control of tumor cell survival, growth, and bone cell differentiation. Blood. 1998; 91:2679-2688.

28. Bass MD, Morgan MR and Humphries MJ. Syndecans shed their reputation as inert molecules. Sci Signal. 2009; 2:pe18.

29. Hayashida K, Bartlett AH, Chen Y and Park PW. Molecular and cellular mechanisms of ectodomain shedding. Anat Rec. 2010; 293:925-937.

30. Purushothaman A, Uyama T, Kobayashi F, Yamada S, Sugahara K, Rapraeger AC and Sanderson RD. Heparanaseenhanced shedding of syndecan-1 by myeloma cells promotes endothelial invasion and angiogenesis. Blood. 2010; 115:2449-2457.

31. Nikolova V, Koo CY, Ibrahim SA, Wang Z, Spillmann D, Dreier R, Kelsch R, Fischgrabe J, Smollich M, Rossi LH, Sibrowski W, Wulfing P, Kiesel L, Yip GW and Gotte M. Differential roles for membrane-bound and soluble syndecan-1 (CD138) in breast cancer progression. Carcinogenesis. 2009; 30:397-407.

32. Yang Y, Macleod V, Miao HQ, Theus A, Zhan F, Shaughnessy JD, Jr., Sawyer J, Li JP, Zcharia E, Vlodavsky I and Sanderson RD. Heparanase enhances syndecan-1 shedding: a novel mechanism for stimulation of tumor growth and metastasis. J Biol Chem. 2007; 282:1332613333.

33. Thanakit V, Ruangvejvorachai $P$ and Sampatanukul $P$. Expression of E-cadherin and syndecan-1 in axillary lymph node metastases of breast cancer with and without extracapsular extension. J Med Assoc Thai. 2008; 91:10871092.

34. Harada K, Masuda S, Hirano M and Nakanuma Y. Reduced expression of syndecan-1 correlates with histologic dedifferentiation, lymph node metastasis, and poor prognosis in intrahepatic cholangiocarcinoma. Hum Pathol. 2003; 34:857-863.

35. Yang N, Mosher R, Seo S, Beebe D and Friedl A. Syndecan-1 in breast cancer stroma fibroblasts regulates extracellular matrix fiber organization and carcinoma cell motility. Am J Pathol. 2011; 178:325-335.

36. Maeda T, Desouky J and Friedl A. Syndecan-1 expression by stromal fibroblasts promotes breast carcinoma growth in 
vivo and stimulates tumor angiogenesis. Oncogene. 2006; 25:1408-1412.

37. Rajgopal R, Butcher M, Weitz JI and Shaughnessy SG. Heparin synergistically enhances interleukin-11 signaling through up-regulation of the MAPK pathway. J Biol Chem. 2006; 281:20780-20787.

38. Ramani VC, Yang Y, Ren Y, Nan L and Sanderson RD. Heparanase plays a dual role in driving hepatocyte growth factor (HGF) signaling by enhancing HGF expression and activity. J Biol Chem. 2011; 286:6490-6499.

39. Elenius K, Salmivirta M, Inki P, Mali M and Jalkanen M. Binding of human syndecan to extracellular matrix proteins. J Biol Chem. 1990; 265:17837-17843.

40. Mali M, Jaakkola P, Arvilommi AM and Jalkanen M. Sequence of human syndecan indicates a novel gene family of integral membrane proteoglycans. J Biol Chem. 1990; 265:6884-6889.

41. Liu W, Litwack ED, Stanley MJ, Langford JK, Lander $\mathrm{AD}$ and Sanderson RD. Heparan sulfate proteoglycans as adhesive and anti-invasive molecules. Syndecans and glypican have distinct functions. J Biol Chem. 1998; 273:22825-22832.

42. Beauvais DM and Rapraeger AC. Syndecan-1-mediated cell spreading requires signaling by alphavbeta 3 integrins in human breast carcinoma cells. Exp Cell Res. 2003; 286:219-232.

43. Lee H, Kim Y, Choi Y, Choi S, Hong E and Oh ES. Syndecan-2 cytoplasmic domain regulates colon cancer cell migration via interaction with syntenin-1. Biochem Biophys Res Commun. 2011; 409:148-153.

44. Lee JH, Park H, Chung H, Choi S, Kim Y, Yoo H, Kim TY, Hann HJ, Seong I, Kim J, Kang KG, Han IO and Oh ES. Syndecan-2 regulates the migratory potential of melanoma cells. J Biol Chem. 2009; 284:27167-27175.

45. Beauvais DM, Ell BJ, McWhorter AR and Rapraeger AC. Syndecan-1 regulates alphavbeta 3 and alphavbeta5 integrin activation during angiogenesis and is blocked by synstatin, a novel peptide inhibitor. J Exp Med. 2009; 206:691-705.

46. Gotte M, Kersting C, Radke I, Kiesel L and Wulfing P. An expression signature of syndecan-1 (CD138), E-cadherin and c-met is associated with factors of angiogenesis and lymphangiogenesis in ductal breast carcinoma in situ. Breast Cancer Res. 2007; 9:R8.

47. O'Connell MP, Fiori JL, Kershner EK, Frank BP, Indig FE, Taub DD, Hoek KS and Weeraratna AT. Heparan sulfate proteoglycan modulation of Wnt5A signal transduction in metastatic melanoma cells. J Biol Chem. 2009; 284:2870428712 .

48. Matsumoto Y, Zhang Q, Akita K, Nakada H, Hamamura K, Tsuchida A, Okajima T, Furukawa K, Urano $\mathrm{T}$ and Furukawa K. Trimeric Tn Antigen on Syndecan 1 Produced by ppGalNAc-T13 Enhances Cancer Metastasis via a Complex Formation with Integrin $\alpha 5 \beta 1$ and Matrix Metalloproteinase 9. J Biol Chem. 2013; 288:24264-24276.
49. Vicente CM, Ricci R, Nader HB and Toma L. Syndecan-2 is upregulated in colorectal cancer cells through interactions with extracellular matrix produced by stromal fibroblasts. BMC Cell Biol. 2013; 14:25.

50. Breshears LM, Schlievert PM and Peterson ML. A disintegrin and metalloproteinase 17 (ADAM17) and epidermal growth factor receptor (EGFR) signaling drive the epithelial response to Staphylococcus aureus toxic shock syndrome toxin-1 (TSST-1). J Biol Chem. 2012; 287:32578-32587.

51. Choi S, Kim JY, Park JH, Lee ST, Han IO and Oh ES. The matrix metalloproteinase-7 regulates the extracellular shedding of syndecan-2 from colon cancer cells. Biochem Biophys Res Commun. 2012; 417:1260-1264.

52. Ramani VC, Purushothaman A, Stewart MD, Thompson CA, Vlodavsky I, Au JLS and Sanderson RD. The heparanase/syndecan-1 axis in cancer: mechanisms and therapies. FEBS J. 2013; 280:2294-2306.

53. Su G, Blaine SA, Qiao D and Friedl A. Membrane type 1 matrix metalloproteinase-mediated stromal syndecan-1 shedding stimulates breast carcinoma cell proliferation. Cancer Res. 2008; 68:9558-9565.

54. Coleman SJ, Chioni AM, Ghallab M, Anderson RK, Lemoine NR, Kocher HM and Grose RP. Nuclear translocation of FGFR1 and FGF2 in pancreatic stellate cells facilitates pancreatic cancer cell invasion. EMBO Mol Med. 2014; 6:467-481.

55. Mahtouk K, Hose D, Raynaud P, Hundemer M, Jourdan M, Jourdan E, Pantesco V, Baudard M, De Vos J, Larroque M, Moehler T, Rossi JF, Reme T, Goldschmidt H and Klein B. Heparanase influences expression and shedding of syndecan-1, and its expression by the bone marrow environment is a bad prognostic factor in multiple myeloma. Blood. 2007; 109:4914-4923.

56. Lovell R, Dunn JA, Begum G, Barth NJ, Plant T, Moss PA, Drayson MT and Pratt G. Soluble syndecan-1 level at diagnosis is an independent prognostic factor in multiple myeloma and the extent of fall from diagnosis to plateau predicts for overall survival. Br J Haematol. 2005; 130:542548.

57. Ben Arush MW, Shafat I, Ben Barak A, Shalom RB, Vlodavsky I and Ilan N. Plasma heparanase as a significant marker of treatment response in children with Hodgkin lymphoma: pilot study. Pediatr Hematol Oncol. 2009; 26:157-164.

58. Kliment CR, Englert JM, Gochuico BR, Yu G, Kaminski N, Rosas I and Oury TD. Oxidative stress alters syndecan-1 distribution in lungs with pulmonary fibrosis. J Biol Chem. 2009; 284:3537-3545.

59. Choi S, Lee H, Choi JR and Oh ES. Shedding; towards a new paradigm of syndecan function in cancer. BMB Rep. 2010; 43:305-310.

60. Ishihara M, Fedarko NS and Conrad HE. Transport of heparan sulfate into the nuclei of hepatocytes. J Biol Chem. 
$1986 ; 261: 13575-13580$.

61. Richardson TP, Trinkaus-Randall V and Nugent MA. Regulation of heparan sulfate proteoglycan nuclear localization by fibronectin. J Cell Sci. 2001; 114:16131623.

62. Purushothaman A, Hurst DR, Pisano C, Mizumoto S, Sugahara K and Sanderson RD. Heparanase-mediated loss of nuclear syndecan-1 enhances histone acetyltransferase (HAT) activity to promote expression of genes that drive an aggressive tumor phenotype. J Biol Chem. 2011; 286:30377-30383.

63. Stewart MD, Ramani VC and Sanderson RD. Shed Syndecan-1 Translocates to the Nucleus of Cells Delivering Growth Factors and Inhibiting Histone Acetylation: A Novel Mechanism of Tumor-Host Crosstalk. J Biol Chem. 2014:jbc. M114. 608455.

64. Kim JH and Park J. Prognostic significance of heme oxygenase-1, S100 calcium-binding protein A4, and syndecan-1 expression in primary non-muscle-invasive bladder cancer. Hum Pathol. 2014; 45:1830-1838.

65. Szarvas T, Reis H, Kramer G, Shariat SF, Vom Dorp F, Tschirdewahn S, Schmid KW, Kovalszky I and Rubben H. Enhanced stromal syndecan-1 expression is an independent risk factor for poor survival in bladder cancer. Hum Pathol. 2014; 45:674-682.

66. Miyake M, Lawton A, Dai Y, Chang M, Mengual L, Alcaraz A, Goodison S and Rosser CJ. Clinical implications in the shift of syndecan-1 expression from the cell membrane to the cytoplasm in bladder cancer. BMC Cancer. 2014; 14:86.

67. Barbareschi M, Maisonneuve P, Aldovini D, Cangi MG, Pecciarini L, Angelo Mauri F, Veronese S, Caffo O, Lucenti A, Palma PD, Galligioni E and Doglioni C. High syndecan-1 expression in breast carcinoma is related to an aggressive phenotype and to poorer prognosis. Cancer. 2003; 98:474-483.

68. Lim GH, Tan PH, Jara-Lazaro AR, Thike AA, Sim WC, Yap VB and Yip GW. Syndecan-1 is a potential biomarker for triple-positive breast carcinomas in Asian women with correlation to survival. Singapore Med J. 2014; 55:468-472.

69. Choi EJ, Yun JA, Jeon EK, Won HS, Ko YH and Kim SY. Prognostic significance of RSPO1, WNT1, P16, WT1, and SDC1 expressions in invasive ductal carcinoma of the breast. World J Surg Oncol. 2013; 11:314.

70. Loussouarn D, Campion L, Sagan C, Frenel JS, Dravet F, Classe JM, Pioud-Martigny R, Berton-Rigaud D, Bourbouloux E, Mosnier JF, Bataille FR and Campone M. Prognostic impact of syndecan-1 expression in invasive ductal breast carcinomas. Br J Cancer. 2008; 98:1993-1998.

71. Tiemann K, Weigel MT, Alkatout I, Wenners AS, Mundhenke H, Schafer FW, Bauer M, Schem C, Maass $\mathrm{N}$, Jonat $\mathrm{W}$ and Mundhenke C. Significance of syndecan-1 expression in ductal carcinoma in situ of the breast. Anticancer Res. 2014; 34:3607-3616.

72. Nguyen TL, Grizzle WE, Zhang K, Hameed O, Siegal GP and Wei S. Syndecan-1 overexpression is associated with nonluminal subtypes and poor prognosis in advanced breast cancer. Am J Clin Pathol. 2013; 140:468-474.

73. Lendorf ME, Manon-Jensen T, Kronqvist P, Multhaupt HA and Couchman JR. Syndecan-1 and syndecan-4 are independent indicators in breast carcinoma. J Histochem Cytochem. 2011; 59:615-629.

74. Baba F, Swartz K, van Buren R, Eickhoff J, Zhang Y, Wolberg W and Friedl A. Syndecan-1 and syndecan-4 are overexpressed in an estrogen receptor-negative, highly proliferative breast carcinoma subtype. Breast Cancer Res Treat. 2006; 98:91-98.

75. Tsanou E, Ioachim E, Briasoulis E, Charchanti A, Damala K, Karavasilis V, Pavlidis N and Agnantis NJ. Clinicopathological study of the expression of syndecan-1 in invasive breast carcinomas. correlation with extracellular matrix components. J Exp Clin Cancer Res. 2004; 23:641650.

76. Leivonen M, Lundin J, Nordling S, von Boguslawski K and Haglund C. Prognostic value of syndecan-1 expression in breast cancer. Oncology. 2004; 67:11-18.

77. Kim YI, Lee A, Lee BH and Kim SY. Prognostic significance of syndecan-1 expression in cervical cancers. J Gynecol Oncol. 2011; 22:161-167.

78. Shinyo Y, Kodama J, Hasengaowa, Kusumoto $\mathrm{T}$ and Hiramatsu Y. Loss of cell-surface heparan sulfate expression in both cervical intraepithelial neoplasm and invasive cervical cancer. Gynecol Oncol. 2005; 96:776-783.

79. Rintala M, Inki P, Klemi P, Jalkanen M and Grenman S. Association of syndecan-1 with tumor grade and histology in primary invasive cervical carcinoma. Gynecol Oncol. 1999; 75:372-378.

80. Wang X, Zuo D, Chen Y, Li W, Liu R, He Y, Ren L, Zhou L, Deng T, Wang X, Ying G and Ba Y. Shed Syndecan-1 is involved in chemotherapy resistance via the EGFR pathway in colorectal cancer. Br J Cancer. 2014; 111:1965-1976.

81. Hashimoto Y, Skacel M and Adams JC. Association of loss of epithelial syndecan-1 with stage and local metastasis of colorectal adenocarcinomas: an immunohistochemical study of clinically annotated tumors. BMC Cancer. 2008; $8: 185$.

82. Lundin M, Nordling S, Lundin J, Isola J, Wiksten JP and Haglund C. Epithelial syndecan-1 expression is associated with stage and grade in colorectal cancer. Oncology. 2005; 68:306-313.

83. Hasengaowa, Kodama J, Kusumoto T, Shinyo Y, Seki N and Hiramatsu Y. Prognostic significance of syndecan-1 expression in human endometrial cancer. Ann Oncol. 2005; 16:1109-1115.

84. Miturski R, Jalkanen M, Postawski K, Jakowicki J and Inki P. Immunohistochemical expression of syndecan-1 in human endometrial cancer cells. Int J Mol Med. 1998; 2:397-401.

85. Roh YH, Kim YH, Choi HJ, Lee KE and Roh MS. 
Syndecan-1 expression in gallbladder cancer and its prognostic significance. Eur Surg Res. 2008; 41:245-250.

86. Wiksten JP, Lundin J, Nordling S, Kokkola A and Haglund C. Comparison of the prognostic value of a panel of tissue tumor markers and established clinicopathological factors in patients with gastric cancer. Anticancer Res. 2008; 28:22792287.

87. Wiksten JP, Lundin J, Nordling S, Lundin M, Kokkola A, von Boguslawski K and Haglund C. Epithelial and stromal syndecan-1 expression as predictor of outcome in patients with gastric cancer. Int J Cancer. 2001; 95:1-6.

88. Xu Y, Yuan J, Zhang Z, Lin L and Xu S. Syndecan-1 expression in human glioma is correlated with advanced tumor progression and poor prognosis. Mol Biol Rep. 2012; 39:8979-8985.

89. Klatka J, Skomra D, Paduch R, Kupisz K, Tryka E, Harytanowicz M and Klos A. [Is syndecan-1 an independent prognostic factor in patients with laryngeal carcinoma?]. Otolaryngol Pol. 2004; 58:933-940.

90. Pulkkinen JO, Penttinen M, Jalkanen M, Klemi P and Grenman R. Syndecan-1: a new prognostic marker in laryngeal cancer. Acta Otolaryngol. 1997; 117:312-315.

91. Nault JC, Guyot E, Laguillier C, Chevret S, Ganne-Carrie N, N'Kontchou G, Beaugrand M, Seror O, Trinchet JC, Coelho J, Lasalle P, Charnaux N, Delehedde M, Sutton A and Nahon P. Serum proteoglycans as prognostic biomarkers of hepatocellular carcinoma in patients with alcoholic cirrhosis. Cancer Epidemiol Biomarkers Prev. 2013; 22:1343-1352.

92. Matsumoto A, Ono M, Fujimoto Y, Gallo RL, Bernfield M and Kohgo Y. Reduced expression of syndecan-1 in human hepatocellular carcinoma with high metastatic potential. Int J Cancer. 1997; 74:482-491.

93. Joensuu H, Anttonen A, Eriksson M, Makitaro R, Alfthan $\mathrm{H}$, Kinnula V and Leppa S. Soluble syndecan-1 and serum basic fibroblast growth factor are new prognostic factors in lung cancer. Cancer Res. 2002; 62:5210-5217.

94. Anttonen A, Heikkila P, Kajanti M, Jalkanen M and Joensuu H. High syndecan-1 expression is associated with favourable outcome in squamous cell lung carcinoma treated with radical surgery. Lung Cancer. 2001; 32:297305 .

95. Kumar-singh S, Jacobs W, Dhaene K, Weyn B, Bogers J, Weyler J and Marck EV. Syndecan-1 expression in malignant mesothelioma: correlation with cell differentiation, WT1 expression, and clinical outcome. J Pathol. 1998; 186:300-305.

96. Kim YJ, Go H, Wu HG, Jeon YK, Park SW and Lee $\mathrm{SH}$. Immunohistochemical study identifying prognostic biomolecular markers in nasopharyngeal carcinoma treated by radiotherapy. Head Neck. 2011; 33:1458-1466.

97. Lakkam B, Majage B, Astekar M, Gugwad RS, Giri G and Ramasahayam S. Immunohistochemical expression of syndecan-1 in oral dysplastic epithelium. J Cancer Res
Ther. 2014; 10:103-106.

98. Al-Otaibi O, Khounganian R, Anil S and Rajendran R. Syndecan-1 (CD 138) surface expression marks cell type and differentiation in ameloblastoma, keratocystic odontogenic tumor, and dentigerous cyst. J Oral Pathol Med. 2013; 42:186-193.

99. Jackson LL, Wade Z, Hessler RB, Abdelsayed R, Rogers JB and Gourin CG. Quantitative analysis of syndecan-1 expression in dysplasia and squamous cell carcinoma of the oral cavity. Laryngoscope. 2007; 117:868-871.

100. Kurokawa H, Zhang M, Matsumoto S, Yamashita Y, Tanaka T, Takamori K, Igawa K, Yoshida M, Fukuyama H, Takahashi T and Sakoda S. Reduced syndecan-1 expression is correlated with the histological grade of malignancy at the deep invasive front in oral squamous cell carcinoma. J Oral Pathol Med. 2006; 35:301-306.

101. Mathe M, Suba Z, Nemeth Z, Tatrai P, Fule T, Borgulya G, Barabas J and Kovalszky I. Stromal syndecan-1 expression is an adverse prognostic factor in oral carcinomas. Oral Oncol. 2006; 42:493-500.

102. Nemeth Z, Szigeti K, Mathe M, Szabo G, Velich N and Suba Z. Effect of induction chemotherapy on changes of laminin and syndecan expression in oral squamous cell carcinomas: a prospective, randomized, clinicopathologic and immunohistochemical study. J Craniofac Surg. 2005; 16:205-212.

103. Kusumoto T, Kodama J, Seki N, Nakamura K, Hongo A and Hiramatsu Y. Clinical significance of syndecan-1 and versican expression in human epithelial ovarian cancer. Oncol Rep. 2010; 23:917-925.

104. Davies EJ, Blackhall FH, Shanks JH, David G, McGown AT, Swindell R, Slade RJ, Martin-Hirsch P, Gallagher JT and Jayson GC. Distribution and clinical significance of heparan sulfate proteoglycans in ovarian cancer. Clin Cancer Res. 2004; 10:5178-5186.

105. Juuti A, Nordling S, Lundin J, Louhimo J and Haglund C. Syndecan-1 expression--a novel prognostic marker in pancreatic cancer. Oncology. 2005; 68:97-106.

106. Ledezma R, Cifuentes F, Gallegos I, Fulla J, Ossandon E, Castellon EA and Contreras HR. Altered expression patterns of syndecan-1 and -2 predict biochemical recurrence in prostate cancer. Asian J Androl. 2011; 13:476-480.

107. Shariat SF, Svatek RS, Kabbani W, Walz J, Lotan Y, Karakiewicz PI and Roehrborn CG. Prognostic value of syndecan-1 expression in patients treated with radical prostatectomy. BJU Int. 2008; 101:232-237.

108. Kiviniemi J, Kallajoki M, Kujala I, Matikainen MT, Alanen K, Jalkanen M and Salmivirta M. Altered expression of syndecan-1 in prostate cancer. Apmis. 2004; 112:89-97.

109. Zellweger T, Ninck C, Mirlacher M, Annefeld M, Glass AG, Gasser TC, Mihatsch MJ, Gelmann EP and Bubendorf L. Tissue microarray analysis reveals prognostic significance of syndecan-1 expression in prostate cancer. Prostate. 2003; 55:20-29. 
110. Anttonen A, Kajanti M, Heikkila P, Jalkanen M and Joensuu H. Syndecan-1 expression has prognostic significance in head and neck carcinoma. Br J Cancer. 1999; 79:558-564.

111. Inki P, Joensuu H, Grenman R, Klemi P and Jalkanen M. Association between syndecan-1 expression and clinical outcome in squamous cell carcinoma of the head and neck. Br J Cancer. 1994; 70:319-323.

112. Jilani I, Wei C, Bekele BN, Zhang ZJ, Keating M, Wierda W, Ferrajoli A, Estrov Z, Kantarjian H, O'Brien SM, Giles FJ and Albitar M. Soluble syndecan-1 (sCD138) as a prognostic factor independent of mutation status in patients with chronic lymphocytic leukemia. Int J Lab Hematol. 2009; 31:97-105.

113. Oh YH and Park CK. Prognostic evaluation of nodal diffuse large B cell lymphoma by immunohistochemical profiles with emphasis on CD138 expression as a poor prognostic factor. J Korean Med Sci. 2006; 21:397-405.

114. Bodoor K, Matalka I, Hayajneh R, Haddad Y and Gharaibeh W. Evaluation of BCL-6, CD10, CD138 and MUM-1 expression in diffuse large B-cell lymphoma patients: CD138 is a marker of poor prognosis. Asian Pac J Cancer Prev. 2012; 13:3037-3046.

115. Kim JM, Lee JA, Cho IS and Ihm CH. Soluble syndecan-1 at diagnosis and during follow up of multiple myeloma: a single institution study. Korean J Hematol. 2010; 45:115119.

116. Aref S, Goda T and El-Sherbiny M. Syndecan-1 in multiple myeloma: relationship to conventional prognostic factors. Hematology. 2003; 8:221-228.

117. Seidel C, Borset M, Hjertner O, Cao D, Abildgaard N, Hjorth-Hansen H, Sanderson RD, Waage A and Sundan A. High levels of soluble syndecan-1 in myeloma-derived bone marrow: modulation of hepatocyte growth factor activity. Blood. 2000; 96(9):3139-3146.

118. Lee JJ. Soluble syndecan-1 (CD138): is it useful as a prognostic factor in Korean patients with multiple myeloma? Korean J Hematol. 2010; 45:143-144.

119. Maisnar V, Touskova M, Tichy M, Krejsek J, Chrobak L, Voglova J and Maly J. The significance of soluble CD138 in diagnosis of monoclonal gammopathies. Neoplasma. 2006; 53:26-29.

120. Janosi J, Sebestyen A, Mikala G, Peto M, Jako J, Domjan G, Nemeth J, Kis Z, Kopper L and Valyi-Nagy I. [Soluble syndecan-1 levels in different plasma cell dyscrasias]. Orv Hetil. 2005; 146:165-168.

121. Andersen NF, Standal T, Nielsen JL, Heickendorff L, Borset M, Sorensen FB and Abildgaard N. Syndecan-1 and angiogenic cytokines in multiple myeloma: correlation with bone marrow angiogenesis and survival. Br J Haematol. 2005; 128:210-217.

122. Kyrtsonis MC, Vassilakopoulos TP, Siakantaris MP, Kokoris SI, Gribabis DA, Dimopoulou MN, Angelopoulou MK and Pangalis GA. Serum syndecan-1, basic fibroblast growth factor and osteoprotegerin in myeloma patients at diagnosis and during the course of the disease. Eur J Haematol. 2004; 72:252-258.

123. Ohshima K, Sugihara M, Suzumiya J, Haraoka S, Kanda M, Shimazaki K, Katoh K, Kumagawa M and Kikuchi M. Basic fibroblast growth factor and fibrosis in Hodgkin's disease. Pathol Res Pract. 1999; 195:149-155.

124. Vassilakopoulos TP, Kyrtsonis MC, Papadogiannis A, Nadali G, Angelopoulou MK, Tzenou T, Dimopoulou MN, Siakantaris MP, Kontopidou FN, Kalpadakis C, Kokoris SI, Dimitriadou EM, Tsaftaridis P, Pizzolo G and Pangalis GA. Serum levels of soluble syndecan-1 in Hodgkin's lymphoma. Anticancer Res. 2005; 25:4743-4746.

125. Tzankov A, Zimpfer A, Pehrs AC, Lugli A, Went P, Maurer $\mathrm{R}$, Pileri $\mathrm{S}$ and Dirnhofer S. Expression of B-cell markers in classical hodgkin lymphoma: a tissue microarray analysis of 330 cases. Mod Pathol. 2003; 16:1141-1147.

126. Passam FH, Alexandrakis MG, Moschandrea J, Sfiridaki A, Roussou PA and Siafakas NM. Angiogenic molecules in Hodgkin's disease: results from sequential serum analysis. Int J Immunopathol Pharmacol. 2006; 19:161-170.

127. Derksen PW, Keehnen RM, Evers LM, van Oers MH, Spaargaren M and Pals ST. Cell surface proteoglycan syndecan-1 mediates hepatocyte growth factor binding and promotes Met signaling in multiple myeloma. Blood. 2002; 99:1405-1410.

128. Teofili L, Di Febo AL, Pierconti F, Maggiano N, Bendandi M, Rutella S, Cingolani A, Di Renzo N, Musto P, Pileri $\mathrm{S}$, Leone $\mathrm{G}$ and Larocca LM. Expression of the c-met proto-oncogene and its ligand, hepatocyte growth factor, in Hodgkin disease. Blood. 2001; 97:1063-1069.

129. Purushothaman A, Chen L, Yang Y and Sanderson RD. Heparanase stimulation of protease expression implicates it as a master regulator of the aggressive tumor phenotype in myeloma. J Biol Chem. 2008; 283:32628-32636.

130. Liu F, Song YQ, Zhang C, Fu ZY, Ping LY, Ying ZT, Zheng W, Wang XP, Xie Y, Lin NJ, Tu MF and Zhu J. [Plasma levels of VEGF-C, VEGF-D, VEGFR-2 and VEGFR-3 in patients with newly diagnosed lymphomas]. Zhongguo Shi Yan Xue Ye Xue Za Zhi. 2011; 19:11841188 .

131. Doussis-Anagnostopoulou IA, Talks KL, Turley H, Debnam P, Tan DC, Mariatos G, Gorgoulis V, Kittas C and Gatter KC. Vascular endothelial growth factor (VEGF) is expressed by neoplastic Hodgkin-Reed-Sternberg cells in Hodgkin's disease. J Pathol. 2002; 197:677-683.

132. Dimtsas GS, Georgiadi EC, Karakitsos P, Vassilakopoulos TP, Thymara I, Korkolopoulou P, Patsouris E, Kittas C and Doussis-Anagnostopoulou IA. Prognostic significance of immunohistochemical expression of the angiogenic molecules vascular endothelial growth factor-A, vascular endothelial growth factor receptor-1 and vascular endothelial growth factor receptor-2 in patients with classical Hodgkin lymphoma. Leuk Lymphoma. 2014; $55: 558-564$. 
133. Khnykin D, Troen G, Berner JM and Delabie J. The expression of fibroblast growth factors and their receptors in Hodgkin's lymphoma. J Pathol. 2006; 208:431-438.

134. Rapraeger AC, Krufka A and Olwin BB. Requirement of heparan sulfate for bFGF-mediated fibroblast growth and myoblast differentiation. Science. 1991; 252:1705-1708.

135. Alexandrakis MG, Passam FH, Pappa CA, Damilakis J, Tsirakis G, Kandidaki E, Passam AM, Stathopoulos EN and Kyriakou DS. Serum evaluation of angiogenic cytokine basic fibroblast growth factor, hepatocyte growth factor and TNF-alpha in patients with myelodysplastic syndromes: correlation with bone marrow microvascular density. Int J Immunopathol Pharmacol. 2005; 18:287-295.

136. Bertolini F, Paolucci M, Peccatori F, Cinieri S, Agazzi A, Ferrucci PF, Cocorocchio E, Goldhirsch A and Martinelli G. Angiogenic growth factors and endostatin in nonHodgkin's lymphoma. Br J Haematol. 1999; 106:504-509.

137. Salven P, Orpana A, Teerenhovi L and Joensuu H. Simultaneous elevation in the serum concentrations of the angiogenic growth factors VEGF and bFGF is an independent predictor of poor prognosis in non-Hodgkin lymphoma: a single-institution study of 200 patients. Blood. 2000; 96:3712-3718.

138. Gharbaran R, Goy A, Tanaka T, Park J, Kim C, Hasan N, Vemulapalli S, Sarojini S, Tuluc M, Nalley K, Bhattacharyya P, Pecora A and Suh KS. Fibroblast growth factor-2 (FGF2) and syndecan-1 (SDC1) are potential biomarkers for putative circulating CD15+/CD30+ cells in poor outcome Hodgkin lymphoma patients. J Hematol Oncol. 2013; 6:62.

139. Rapraeger AC. Synstatin: a selective inhibitor of the syndecan-1-coupled IGF1R- $\alpha$ v $\beta 3$ integrin complex in tumorigenesis and angiogenesis. FEBS J. 2013; 280:22072215.

140. Rapraeger AC, Ell BJ, Roy M, Li X, Morrison OR, Thomas GM and Beauvais DM. Vascular endothelial-cadherin stimulates syndecan-1-coupled insulin-like growth factor-1 receptor and cross-talk between alphaVbeta3 integrin and vascular endothelial growth factor receptor 2 at the onset of endothelial cell dissemination during angiogenesis. FEBS J. 2013; 280:2194-2206.

141. Jagannath S, Chanan-Khan AA, Heffner LT, Avigan D, Lutz RJ and Uherek C. An antibodydrug conjugate directed against CD138, Shows clinical activity in a phase I study in patients with relapsed or relapsed/refractory multiple myeloma. Blood. 2010; 116:3060a.

142. Kelly KR, Chanan-Khan A, Somlo G, Heffner LT, Siegel DS, Zimmerman TM, Jagannath S, Munshi NC, Lonial S and Roy V. Indatuximab ravtansine (BT062) in combination with lenalidomide and low-dose dexamethasone in patients with relapsed and/or refractory multiple myeloma: clinical activity in len/dex-refractory patients. Blood. 2013; 122:758-758.

143. Rousseau C, Ferrer L, Supiot S, Bardiès M, Davodeau F, Faivre-Chauvet A, Baumgartner P, Wijdenes J, Lacombe
$\mathrm{M}$ and Barbet J. Dosimetry results suggest feasibility of radioimmunotherapy using anti-CD138 (B-B4) antibody in multiple myeloma patients. Tumor Biol. 2012; 33:679-688.

144. Orecchia P, Conte R, Balza E, Petretto A, Mauri P, Mingari $\mathrm{MC}$ and Carnemolla B. A novel human anti-syndecan-1 antibody inhibits vascular maturation and tumour growth in melanoma. Eur J Cancer. 2013; 49:2022-2033.

145. Bae J, Tai YT, Anderson KC and Munshi NC. Novel epitope evoking CD138 antigen-specific cytotoxic $\mathrm{T}$ lymphocytes targeting multiple myeloma and other plasma cell disorders. Br J Haematol. 2011; 155:349-361.

146. Remacle AG, Golubkov VS, Shiryaev SA, Dahl R, Stebbins JL, Chernov AV, Cheltsov AV, Pellecchia M and Strongin AY. Novel MT1-MMP small-molecule inhibitors based on insights into hemopexin domain function in tumor growth. Cancer Res. 2012; 72:2339-2349.

147. Low JA, Johnson MD, Bone EA and Dickson RB. The matrix metalloproteinase inhibitor batimastat (BB-94) retards human breast cancer solid tumor growth but not ascites formation in nude mice. Clin Cancer Res. 1996; 2:1207-1214.

148. Endo K, Takino T, Miyamori H, Kinsen H, Yoshizaki T, Furukawa $M$ and Sato H. Cleavage of syndecan-1 by membrane type matrix metalloproteinase-1 stimulates cell migration. J Biol Chem. 2003; 278:40764-40770.

149. Macaulay VM, O’Byrne KJ, Saunders MP, Braybrooke JP, Long L, Gleeson F, Mason CS, Harris AL, Brown P and Talbot DC. Phase I study of intrapleural batimastat (BB94), a matrix metalloproteinase inhibitor, in the treatment of malignant pleural effusions. Clin Cancer Res. 1999; 5:513520 .

150. Liu CJ, Lee PH, Lin DY, Wu CC, Jeng LB, Lin PW, Mok KT, Lee WC, Yeh HZ, Ho MC, Yang SS, Lee CC, Yu MC, Hu RH, Peng CY, Lai KL, et al. Heparanase inhibitor PI88 as adjuvant therapy for hepatocellular carcinoma after curative resection: a randomized phase II trial for safety and optimal dosage. J Hepatol. 2009; 50:958-968.

151. Basche M, Gustafson DL, Holden SN, O’Bryant CL, Gore L, Witta S, Schultz MK, Morrow M, Levin A and Creese BR. A phase I biological and pharmacologic study of the heparanase inhibitor PI-88 in patients with advanced solid tumors. Clin Cancer Res. 2006; 12:5471-5480.

152. Winterhoff B, Freyer L, Hammond E, Giri S, Mondal S, Roy D, Teoman A, Mullany SA, Hoffmann R and von Bismarck A. PG545 enhances anti-cancer activity of chemotherapy in ovarian models and increases surrogate biomarkers such as VEGF in preclinical and clinical plasma samples. Eur J Cancer. 2015.

153. Schultes BC, Chu CL, Long A, Sun E, Kurtagic E, Beccati D, Pradines J, Miller P, Ryan DP and Flaherty K. The effect and mechanism of M402 on gemcitabine uptake into pancreatic tumors. J Clin Oncol. 2014.

154. Ritchie JP, Ramani VC, Ren Y, Naggi A, Torri G, Casu B, Penco S, Pisano C, Carminati $\mathrm{P}$ and Tortoreto M. 
SST0001, a chemically modified heparin, inhibits myeloma growth and angiogenesis via disruption of the heparanase/ syndecan-1 axis. Clin Cancer Res. 2011; 17:1382-1393.

155. Ramya D and Grace VB. Effect of all-trans retinoic acid (ATRA) on syndecan-1 expression and its chemoprotective effect in benzo $(\alpha)$ pyrene-induced lung cancer mice model. Immunopharmacol Immunotoxicol. 2012; 34:1020-1027.

156. Ding K, Lopez-Burks M, Sánchez-Duran JA, Korc M and Lander AD. Growth factor-induced shedding of syndecan-1 confers glypican-1 dependence on mitogenic responses of cancer cells. J Cell Biol. 2005; 171:729-738.

157. Alessi P, Leali D, Camozzi M, Cantelmo A, Albini A and Presta M. Anti-FGF2 approaches as a strategy to compensate resistance to anti-VEGF therapy: longpentraxin 3 as a novel antiangiogenic FGF2-antagonist. Eur Cytokine Netw. 2009; 20:225-234.

158. Cullen L, Kelly L, Connor SO and Fitzgerald DJ. Selective cyclooxygenase-2 inhibition by nimesulide in man. J Pharmacol Exp Ther. 1998; 287:578-582.

159. Paul AG, Sharma-Walia N and Chandran B. Targeting KSHV/HHV-8 latency with COX-2 selective inhibitor nimesulide: a potential chemotherapeutic modality for primary effusion lymphoma. PloS one. 2011; 6:e24379.

160. Huang H, Ding R, Xiang X and Hou J. [Effect of zoledronic acid on the growth and CD138 expression of myeloma cell line KM3]. Zhonghua xue ye xue za zhi= Zhonghua xueyexue zazhi. 2009; 30:183-185.

161. Dedes P, Gialeli C, Tsonis A, Kanakis I, Theocharis A, Kletsas D, Tzanakakis G and Karamanos N. Expression of matrix macromolecules and functional properties of breast cancer cells are modulated by the bisphosphonate zoledronic acid. Biochim Biophys Acta. 2012; 1820:19261939.

162. Malavaki CJ, Roussidis AE, Gialeli C, Kletsas D, Tsegenidis $\mathrm{T}$, Theocharis AD, Tzanakakis GN and Karamanos NK. Imatinib as a key inhibitor of the plateletderived growth factor receptor mediated expression of cell surface heparan sulfate proteoglycans and functional properties of breast cancer cells. FEBS J. 2013; 280:24772489.

163. Guo B, Chen M, Han Q, Hui F, Dai H, Zhang W, Zhang Y, Wang Y, Zhu H and Han W. CD138-directed adoptive immunotherapy of chimeric antigen receptor (CAR)modified $\mathrm{T}$ cells for multiple myeloma. J Cell Immunother. 2015.

164. Mundt F, Heidari-Hamedani G, Nilsonne G, Metintas M, Hjerpe A and Dobra K. Diagnostic and prognostic value of soluble syndecan-1 in pleural malignancies. Biomed Res Int. 2014; 419853:24.

165. Bologna-Molina R, Gonzalez-Gonzalez R, MosquedaTaylor A, Molina-Frechero N, Damian-Matsumura $P$ and Dominguez-Malagon H. Expression of syndecan-1 in papillary carcinoma of the thyroid with extracapsular invasion. Arch Med Res. 2010; 41:33-37.
166. Barbouri D, Afratis N, Gialeli C, Vynios DH, Theocharis $\mathrm{AD}$ and Karamanos NK. Syndecans as modulators and potential pharmacological targets in cancer progression. Frontiers in oncology. 2014; 4.

167. Liu Z, Xu J, He J, Zheng Y, Li H, Lu Y, Qian J, Lin P, Weber DM and Yang J. A critical role of autocrine sonic hedgehog signaling in human CD138+ myeloma cell survival and drug resistance. Blood. 2014; 124:2061.

168. Landgraf P, Mikhaylova M, Macharadze T, Borutzki C, Zenclussen A-C, Wahle P and Kreutz MR. Binding of Y-P30 to syndecan 2/3 regulates the nuclear localization of CASK. PLoS One. 2014; 9:e85924.

169. De Oliveira T, Abiatari I, Raulefs S, Sauliunaite D, Erkan M, Kong B, Friess H, Michalski CW and Kleeff J. Syndecan-2 promotes perineural invasion and cooperates with K-ras to induce an invasive pancreatic cancer cell phenotype. Mol Cancer. 2012; 11:19.

170. Itoua Maiga R, Lemieux J, Roy A, Simard C and Neron S. Flow cytometry assessment of in vitro generated CD138+ human plasma cells. Biomed Res Int. 2014; 536482:9.

171. Costes V, Magen V, Legouffe E, Durand L, Baldet P, Rossi JF, Klein B and Brochier J. The Mi15 monoclonal antibody (anti-syndecan-1) is a reliable marker for quantifying plasma cells in paraffin-embedded bone marrow biopsy specimens. Hum Pathol. 1999; 30:1405-1411.

172. Asplund A, Ostergren-Lunden G, Camejo G, StillemarkBillton P and Bondjers G. Hypoxia increases macrophage motility, possibly by decreasing the heparan sulfate proteoglycan biosynthesis. J Leukoc Biol. 2009; 86:381388.

173. Gokden N, Greene GF, Bayer-Garner IB, Spencer HJ, Sanderson RD and Gokden M. Expression of CD138 (Syndecan-1) in renal cell carcinoma is reduced with increasing nuclear grade. Appl Immunohistochem Mol Morphol. 2006; 14:173-177.

174. Seftalioglu A and Karakus S. Syndecan-1/CD138 expression in normal myeloid, acute lymphoblastic and myeloblastic leukemia cells. Acta Histochem. 2003; 105:213-221.

175. Hammond E, Handley P, Dredge K and Bytheway I. Mechanisms of heparanase inhibition by the heparan sulfate mimetic PG545 and three structural analogues. FEBS Open Bio. 2013; 3:346-351.

176. Zhou H, Roy S, Cochran E, Zouaoui R, Chu CL, Duffner J, Zhao G, Smith S, Galcheva-Gargova Z and Karlgren J. M402, a novel heparan sulfate mimetic, targets multiple pathways implicated in tumor progression and metastasis. PLoS One. 2011; 6:e21106.

177. Hammond E, Khurana A, Shridhar V and Dredge K. The Role of Heparanase and Sulfatases in the Modification of Heparan Sulfate Proteoglycans within the Tumor Microenvironment and Opportunities for Novel Cancer Therapeutics. Front Oncol. 2014; 4.

178. Gemo AT, Deshpande AM, Palencia S, Bellovin DI, 
Brennan TJ, Patil NS, Huang C, Los G and Pierce KL. FPA144: A therapeutic antibody for treating patients with gastric cancers bearing FGFR2 gene amplification. Cancer Res. 2014; 74:5446-5446.

179. Younes A, Gordon L, Kim S, Romaguera J, Copeland AR, de Castro Farial S, Kwak L, Fayad L, Hagemeister $\mathrm{F}$ and Fanale M. Phase I multi-dose escalation study of the anti-CD19 maytansinoid immunoconjugate SAR3419 administered by intravenous (IV) infusion every 3 weeks to patients with relapsed/refractory B-cell non-Hodgkin's lymphoma (NHL). Blood. 2009; 114.

180. Hong DS, Garrido-Laguna I, Ekmekcioglu S, Falchook GS, Naing A, Wheler JJ, Fu S, Moulder SL, Piha-Paul $\mathrm{S}$ and Tsimberidou AM. Dual inhibition of the vascular endothelial growth factor pathway: a phase 1 trial evaluating bevacizumab and AZD2171 (cediranib) in patients with advanced solid tumors. Cancer. 2014; 120:2164-2173.

181. Smith DC, Gordon M, Messersmith W, Chugh R, Mendelson D, Dupont J, Stagg R, Kapoun AM, Xu L and Brachmann RK. Abstract B79: A first-in-human Phase 1 study of anti-cancer stem cell (CSC) agent OMP54F28 (FZD8-Fc) targeting the WNT pathway in patients with advanced solid tumors. Mol Cancer Ther. 2013; 12:B79-B79.

182. Gerber DE RS, Morgensztern D, Kelly RJ, Burns TF, Chavez AL, Spigel DR, Wehbe AM, Sorensen R, Weaver DT, Horobin J, Keegan M, Scaglioni PP, Camidge DR, VS6063 PIs. A phase 2 study of defactinib (VS-6063), a cancer stem cell inhibitor that acts through inhibition of focal adhesion kinase (FAK), in patients with KRAS-mutant nonsmall cell lung cancer. J Clin Oncol. 2014; 32(5s).

183. Soria JC, Gan HK, Arkenau HT, Blagden SP, Plummer R, Ranson M, Evans T, Zalcman G, Bahleda R and Hollebecque A. Phase I clinical and pharmacologic study of the focal adhesion kinase (FAK) inhibitor GSK2256098 in pts with advanced solid tumors. J Clin Oncol. 2012. 